\title{
DEFENDING REFUGEES: A CASE FOR PROTECTIVE PROCEDURAL SAFEGUARDS IN THE PERSECUTOR BAR ANALYSIS
}

\author{
Charles Shane Ellison*
}

\begin{abstract}
For refugees and asylum seekers, application of the so-called persecutor bar is tantamount to a death sentence. However, the Board of Immigration Appeals - without any real deliberation - has arrived at an interpretation of a generic-relief, burden-shifting regulation to allow for application of the persecutor bar based upon very little evidence. Even mere membership in a group with a poor human rights record has been held sufficient to switch the burden of proof and apply the bar. While the recent holding of Matter of Negusie, 27 I\&N Dec. 347 (June 28, 2018) can be read and understood largely as a victory for refugees on the question of the duress defense to the bar, that decision is under review by the AG. Additionally, more work is needed to solidify capacious procedural safeguards in the application of the bar ab initio before adjudicators even reach questions of duress. Safeguards are crucial because the current procedures allow adjudicators to apply the bar merely where there is possible assistance in persecution. Given the dearth of past scholarly attention devoted to procedural application of the persecutor bar, this article aims to contribute to this nascent, timely, and largely-untouched discussion. I argue here that it is only where the record contains a preponderance of the evidence to allow an adjudicator to find actual assistance in persecution-and the applicant is given fair notice and opportunity to respond - that the statute, case law, and international law allow the persecutor bar to be applied.
\end{abstract}

\footnotetext{
* Director of the Immigrant and Refugee Clinic, Special Assistant Professor of Law, Creighton University School of Law; Legal Director, Immigrant Legal Center. This article was borne out of my briefing of the issue as co-counsel with Professor Benjamin Casper Sanchez for various amici curiae before the Board of Immigration Appeals in Matter of Negusie, and the U.S. Court of Appeals for the Eighth and Ninth Circuits. I am particularly indebted to Professor Casper Sanchez for his guidance, mentorship, and significant contributions to the article. I am also very grateful for the invaluable input and feedback of Professors Sabrineh Ardalan, Kate Evans, Rachel Settlage, Maureen Sweeney, Kevin Ruser, and David Weber along with the participants at the 2018 Immigration Law Scholars and Teachers Workshop. I also thank the editorial staff of the Georgetown Immigration Law Journal for their insightful comments. Soli Deo gloria. (C) 2019, Charles Shane Ellison.
} 


\section{TABLE OF CONTENTS}

INTRODUCTION $\ldots \ldots \ldots \ldots \ldots \ldots \ldots \ldots \ldots \ldots$

I. Recent Historical Context and Evolution Of The Interpretation And Application Of The Persecutor Bar . . . .

A. From Fedorenko To Negusie: The Duress Question .... . 220

B. Past Expansive Application Of The Persecutor Bar Through

Lax Procedures. . . . . . . . . . . . . . . . .

II. The Need to Reformulate The Persecutor Bar's Procedural

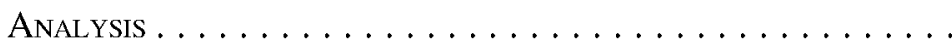
A. Contrasting the Generic-Relief Regulations with the
Regulations Specific to Applications for Asylum and Withholding . .....................
B. Decisions Casting Doubt on the Use of the Generic-Relief Regulation in the Persecutor Bar Context . . . . . . . 236
C. Guiding Principles for Crafting Adequate Procedural Safeguards.

III. The Four Substantive Preliminary Findings Regarding Whether The Applicant Assisted Or Participated In Persecution. . . . . . . . . . . . . . . . . . . . . . . 240
A. An Act Sufficiently Severe To Constitute Persecution ....
B. On Account Of A Protected Characteristic Of The Victim .
C. A Connection Between The Applicant's Conduct And The Identified Act Of Persecution . . . . . . . . . . . . . . 244
D. Prior or Contemporaneous Knowledge . . . . . . . . . 247

IV. The Necessary Procedural Safeguards Required to Apply the PERSECUTOR BAR . . . . . . . . . . . . . . . . .

A. A Framework No Less Protective Than The Procedures The Board Has Adopted For Similar Bars With Less Serious Consequences........................... 249

B. Proposed Procedural Safeguards .............. 252

1. DHS Must Bear The Initial Burden Of Proof . . . . . 253

2. Only A Preponderance Of The Evidence Can Justify Application Of The Bar. . . . . . . . . . . 255

3. The Applicant Must Have Notice And Opportunity To Respond ..................... 257 
Conclusion $\ldots \ldots \ldots \ldots \ldots \ldots \ldots \ldots \ldots \ldots \ldots \ldots \ldots \ldots \ldots \ldots \ldots \ldots \ldots$

\section{INTRODUCTION}

The persecutor bar is an absolute disqualifier for asylum and refugee protections, withholding of removal, and several other forms of relief ${ }^{1}$ for those "the Attorney General determines" or "decides" have "ordered, incited, assisted, or otherwise participated in the persecution of any person on account of race, religion, nationality, membership in a particular social group, or political opinion." ${ }^{\prime 2}$ It is a dramatic penalty that permits a noncitizen's deportation to a country even where she faces a clear probability of fatal harm. ${ }^{3}$ Yet, for decades the Board of Immigration Appeals ${ }^{4}$ (BIA or Board) - the chief administrative body responsible for construing the relevant U.S. legal provisions - had taken a hardline approach to the issue. ${ }^{5}$ The BIA had adopted what amounts to a strict liability test for application of the bar, holding that only the "objective effects" of an applicant's actions mattered, irrespective of her motivation or intent. ${ }^{6}$ As such, it had concluded that even a refugee coerced into assisting a persecutor would be barred from protection, ${ }^{7}$ a conclusion of devastating consequence for refugees forced to harm another. ${ }^{8}$ Indeed, a tragic

1. As discussed in greater detail below, it is also an unqualified bar to Temporary Protected Status, Nicaraguan Adjustment and Central American Relief Act (NCARA) protection. See infra note 47 and accompanying text.

2. 8 U.S.C. $\$ \S 1158(\mathrm{~b})(2)(\mathrm{A})(\mathrm{i}) ; 1231$ (b)(3). Asylum is a discretionary form of relief available to noncitizens in the U.S. who meet the definition of a refugee (i.e., those who are outside of their country of nationality who are unable or unwilling to return because of past persecution or a well-founded fear of future persecution on account of race, religion, nationality, membership in a particular social group, or political opinion). See 8 U.S.C. $\$ \$ 1158(b)(1)(A) ; 1101(a)(42)$. Withholding of removal is a similar form of protection - but is mandatory-for those facing a clear probability of persecution in their home country on account of the same protected grounds listed in the asylum statute. See 8 U.S.C. \$1231(b)(3); I.N.S. v. Stevic, 467 U.S. 407 (1984).

3. See Gao v. U.S. Atty. Gen., 500 F.3d 93, 98 (2d Cir. 2007) ("In evaluating a persecutor bar claim, it must be remembered that this provision authorizes the deportation of individuals who have established that they would likely be persecuted."). While some have argued that protection under the Convention Against Torture (CAT) - which does not have a persecutor bar — could protect refugee-persecutors facing a clear probability of death in their home country, see Tasha Wiesman, Denying Relief To The Persecutor: An Argument In Favor of Adopting the Dissenting Opinion of Negusie v. Holder, $44 \mathrm{~J}$. MARSHALL L. REV. 559, 579 (2011), this will not be true in every case given the onerous state actor and acquiescence requirements for CAT relief. Indeed, many refugees facing non-governmental persecution back home will find it difficult to obtain CAT protection. See e.g., Fuentes-Erazo v. Sessions, 848 F.3d 847, 852 (8th Cir. 2017) (describing the "more onerous" CAT standard for government protection); Garcia v. Holder, 746 F.3d 869, 874 (8th Cir. 2014) ("Without more, the inability of Guatemalan police to curtail MS-13 violence does not entitle Somoza to CAT relief.") (emphasis added).

4. The BIA oversees challenges filed to asylum decisions issued by Immigration Judges (IJ), who in turn provide de novo review of asylum decisions referred from the Asylum Officers (AO), within the United States Citizenship and Immigration Services (USCIS). See generally DeBORAH E. ANKER, LAw OF ASYlum IN THE UnITED STATES, (2017 ed.). This article refers to these three entities collectively as "adjudicators."

5. Kate Evans, Drawing Lines Among the Persecuted, 101 MinN. L. REv. 453, 473 (2016).

6. In re Laipenieks, 18 I. \& N. Dec. 433, 434-36 (B.I.A. 1983), rev'd, Laipenieks v. INS, 750 F.2d 1427 (9th Cir. 1985); Evans, supra note 7.

7. In re Fedorenko, 19 I. \& N. Dec. 57 (B.I.A. 1984); In re Rodriguez-Majano, 19 I. \& N. Dec. 811 (B.I.A. 1988) (holding that "participation or assistance of an alien in persecution need not be of his own volition to bar him from relief").

8. Evans, supra note 7. 
though commonplace form of persecution around the world has included subjecting an individual — a child soldier, for example—-to serve as the persecutor's weapon against her friend or family member. ${ }^{9}$ While being forced under threat of death to harm loved ones is perhaps the most horrific form of persecution imaginable, even refugees trapped in this Sophie's choice would be barred from relief under the rule originally espoused by the Board.

In 2009, the Supreme Court intervened to correct a latent legal error in the BIA's analysis, an error which served to anchor the Board's "objective effects" test. ${ }^{10}$ In Negusie v. Holder, the Supreme Court held that the BIA had misread its past precedent to treat as foreclosed the question of whether a refugee - coerced into assisting with persecution-must be barred from protection. ${ }^{11}$ However, the Court stopped short of offering an answer to the duress defense question. ${ }^{12}$ Instead, the Court elected to remand the matter to the Board to reexamine the issue unencumbered by its prior flawed legal analysis. ${ }^{13}$

For the next eight years, however, the BIA failed to take up the Supreme Court's call. It was not until 2016-through the issuance of an amicus invitation and requests for supplemental briefing - that the Board signaled it was finally prepared to address the issue. In its request for amicus briefs, ${ }^{14}$ the Board presented two questions. First, does "an involuntariness or duress exception exist to limit the application of the persecutor bar ...." ${ }^{15}$ And second, "[a]ssuming it is necessary to acknowledge a duress exception to the persecutor bar, what ought to be the standards (including relevant burdens of proof) to determine if an applicant for asylum qualifies for such an exception?" 16 While there has been excellent and thoughtful scholarly discussion of the first prong of the BIA's question, ${ }^{17}$ there is virtually no such treatment

9. See Matter of Negusie, 27 I. \& N. Dec. 347 (B.I.A. 2018); Lukwago v. Ashcroft, 329 F.3d 157, 164 (3d Cir. 2003); see also U.N. Secretary-General, Children and armed conflict: Report of the Secretary-General, ITI 172-73, U.N. Doc. A/62/609-S/2007/757 (Dec. 21, 2007); Susan Tiefenbrun, Child Soldiers, Slavery and the Trafficking of Children, 31 FoRdHAM INT'L L.J. 415, 422 (2008) (estimating up to 250,000 child soldiers participating in armed conflicts as of that time).

10. Negusie v. Holder, 555 U.S. 511 (2009).

11. Id.

12. $I d$.

13. Id. at 1165-67. The Court relied upon the principles of Chevron to defer to the agencies interpretation of the statute. While beyond the scope of this article, it is worth noting that the robust form of deference to administrative agencies that has emanated from Chevon is likely in need of correction. Justice Kennedy, in his recent concurrence in Pereira v. Sessions, chastised the Courts of Appeals' "troubling," "reflexive deference" given to agencies in the name of Chevron even where "Congress's intent [can] be discerned" using "the ordinary tools of statutory construction." 138 S. Ct. 2105, 2120 (2018) (Kennedy, J., concurring). Justice Kennedy notes that "it seems necessary and appropriate to reconsider, in an appropriate case, the premises that underlie Chevron and how courts have implemented that decision." Id. at 2121.

14. See Amicus Invitation No. 16-08-08 (Duress Exception to Persecutor Bar), BD. OF IMMIGR. APPEALS (Aug. 8, 2016), https://www.justice.gov/eoir/file/882811/download [hereinafter Amicus Invitation].

15. Id.

16. $I d$.

17. Evans, supra note 7, at 457-58 n.16 (citing Stephen J. Massey, Individual Responsibility for Assisting the Nazis in Persecuting Civilians, 71 Minn. L. Rev. 97, 112-16, 113 n.90 (1986); Melani 
of the second. ${ }^{18}$ The Board was working with a relatively clean slate on which to craft procedural safeguards. ${ }^{19}$

On June 28, 2018, more than nine years after the Supreme Court's decision to remand the matter, the Board finally issued its decision in Matter of Negusie ${ }^{20}$ which affirmed that the persecutor bar does indeed have a duress defense. ${ }^{21}$ Additionally, the Board provided some of the contours to the procedures involved in the application of the persecutor bar and its duress exception. ${ }^{22}$ A number of the procedural safeguards proposed by Mr. Negusie and amici were adopted by the Board, even while the Board found that Mr. Negusie failed to qualify for the defense..$^{23}$

However, on the question of one particular point of procedure in relation to burdens of proof, the Board resisted addressing an error that had been flagged in briefing. ${ }^{24}$ In decisions leading up to Matter of Negusie, the Board-without any real deliberation - had arrived at an interpretation of a generic-relief, burden-shifting regulation (hereinafter "generic-relief regulation") ${ }^{25}$ to allow for

Johns, Comment, Adjusting the Asylum Bar: Negusie v. Holder and the Need To Incorporate a Defense of Duress into the "Persecutor Bar," 40 Golden Gate U. L. Rev. 235, 261 (2010); Karl Goodman, Comment, Negusie v. Holder: The End of the Strict Liability Persecutor Bar?, 13 CUNY L. REV. 143, 159-66 (2009); Tasha Wiesman, Comment, Denying Relief to the Persecutor: An Argument in Favor of Adopting the Dissenting Opinion of Negusie v. Holder, 44 J. Marshall L. Rev. 559 (2011); Bryan Lonegan, Sinners or Saints: Child Soldiers and the Persecutor Bar to Asylum After Negusie v. Holder, 31 B.C. ThIRd World L.J. 71 (2011); Abbe L. Dienstag, Comment, Fedorenko v. United States: War Crimes, the Defense of Duress, and American Nationality Law, 82 COLUM. L. REv. 120, 162-70 (1982); Leah Durland, Comment, Overcoming the Persecutor Bar: Applying a Purposeful Mens Rea Requirement to 8 U.S.C. $\$ 1101(a)(42), 32$ HamLine L. Rev. 571, 596-608 (2009); Mark Philipp, Case Note, Assisting in Persecution: Analyzing the Decision in Negusie v. Gonzales, 231 F. App'x 325 (5th Cir. 2007), 34 S. ILL. U. L.J. 417, 441-44 (2010)).

18. The present article seeks to address that void, an endeavor made even more timely by the issuance of the Board's long-awaited decision Matter of Negusie, 27 I. \& N. Dec. 347 (B.I.A. 2018).

19. Evans, supra note 7.

20. Matter of Negusie, 27 I. \& N. Dec. 347 (2018).

21. Id.

22. Id.

23. Id. at 347. The procedural framework I proposed (as counsel for amici) that the BIA largely adopted in Negusie consisted of the following: First, the persecutor bar analysis must begin with a determination regarding eligibility for relief. Then, the adjudicator must make findings regarding the substantive elements of "assistance or participation" in persecution, which are: (1) an identifiable act sufficiently severe to constitute persecution; (2) a nexus between that identified act of harm and a protected characteristic of the victim; (3) the applicant's conduct constituted genuine assistance or participation in that identified act of persecution; and (4) the applicant had the requisite prior or contemporaneous culpable knowledge. This initial showing is DHS's burden. See Proposed Brief for American Immigration Lawyers Association \& National Justice for our Neighbors as Amici Curiae, Matter of Amicus Invitation No. 16-08-08, https:/www.immigrantlc.org/wp-content/uploads/2018/01/Matter-of-Negusie-AmicusCuriae.pdf [hereinafter AILA Proposed Brief]; see generally Kate Evans, Practice Alert: Litigation Update in Negusie v. Holder: The Board of Immigration Appeals Nears Decision on the Persecutor Bar (Oct. 2017), http://www.uidaho.edu/-/media/UIdaho-Responsive/Files/law/academics/practical-skills/ clinics/immigration/Briefs/Practice-Alert-Persecutor-Bar-at-the-BIA-October-2017.pdf; Negusie, 27 I. \& N. Dec. at 366.

24. See AILA Proposed Brief, supra note 25.

25. 8 C.F.R. $\S 1240.8(\mathrm{~d})$. The regulation provides that "[i]f the evidence indicates that one or more of the grounds for mandatory denial of the application for relief may apply, the alien shall have the burden of proving by a preponderance of the evidence that such grounds do not apply." I call this the "genericrelief regulation" because it applies generally to "application[s] for relief," rather than to any particular form of relief or protection. See id. 
application of the persecutor bar based upon very little evidence. ${ }^{26}$ Those decisions had suggested that pointing to any evidence of possible participation in persecution-even mere membership in a group with a poor human rights record-was sufficient to switch the burden of proof and require an applicant for asylum or withholding of removal to effectively prove a negative (i.e., to prove he or she did not assist or otherwise participate in persecution). ${ }^{27}$ Frequently, this interpretation was coupled with an attack on the credibility of the applicant. ${ }^{28}$ In their combination, this two-pronged approach was utilized to apply the bar even in the absence of evidence that an applicant was actually involved in persecution. ${ }^{29}$ Indeed, some decisions had suggested that it was unnecessary to show the applicant's actual assistance in persecution; rather, the mere possibility of assistance had been sufficient to apply the bar. ${ }^{30}$

To describe this particular interpretation and application of the genericrelief regulation ${ }^{31}$ in the persecutor bar context, I have coined the term "laxprocedure approach." The overriding concern with this approach is that it cannot be properly squared with the larger structure of the Immigration and Nationality Act (INA). ${ }^{32}$ Nor is it in keeping with the more robust procedural safeguards developed by the Board in the context of analogous bars. ${ }^{33}$ In Matter of Negusie, amici advocated for a construction of the generic-relief regulation that would have eliminated the risk entailed in the lax-procedure approach by requiring the Department of Homeland Security (DHS) to establish by a preponderance of the evidence that the applicant actually assisted or participated in persecution. ${ }^{34}$ However, instead of adopting that proposed construction, the Board set the government's burden at a prima facie standard and did not clearly repudiate its past problematic reasoning regarding the "low burden" embedded within the generic-relief regulation. ${ }^{35}$ While the overall holding in Matter of Negusie can be read and understood largely as a victory for refugees on the question of the duress defense, that decision is under review by the Attorney General (AG). ${ }^{36}$ Additionally, more work is

\footnotetext{
26. See infra Section I.B.

27. See id.

28. See id. Being forced to prove a negative is difficult under any circumstance, but it is even more daunting for a refugee whose credibility has been impugned.

29. See infra Section I.B.

30. See id. A paradigmatic example of this approach can be found in the Board's recent decision Matter of M-B-C-, 27 I. \& N. Dec. 31, 38 (B.I.A. 2017). A more fulsome discussion of $M-B$ - $C$ - can be found below in Section I.B.1.

31. See supra note 27.

32. See infra Section IV.A.

33. Seeid.

34. See AILA Proposed Brief, supra note 26.

35. See Matter of Negusie, 27 I. \& N. Dec. 347, 366 (B.I.A. 2018).

36. See Matter of Negusie, 27 I. \& N. Dec. 481 (A.G. 2018). The amicus team involved in earlier rounds of briefing determined to simply resubmit the previously filed briefs in response to AG Sessions' October 18, 2018 request for briefs. On February 14, 2019, the Senate confirmed William Barr to replace Sessions. See Senate confirms William Barr as attorney general in 54-to-45 vote, available at https://www. washingtonpost.com/world/national-security/william-barr-expected-to-be-confirmed-as-attorney-general-
} 
needed to solidify capacious procedural safeguards in the application of the bar $a b$ initio before adjudicators even reach the question of duress.

Safeguards are crucial here because the lax-procedure approach allows for application of the bar even in the absence of evidence of actual assistance in persecution. As such, a refugee may find herself in a situation where the burden is on her to prove in the abstract why her actions did not assist in persecution, or was the result of duress, before it is even clear what assistance she is alleged to have given. Moreover, the AG's decision to refer Matter of Negusie to himself portends further erosion of safeguards in this context, or at a minimum, ensures that this matter will be the subject of debate well into the future. Given the dearth of past scholarly attention devoted to procedural safeguards related to application of the persecutor bar, and that the topic is currently being litigated, this article aims to contribute to this nascent, timely, and largely-untouched discussion. I argue here that it is only where the record contains a preponderance of evidence to allow an adjudicator to find actual assistance in persecution does the statute, case law, and international law allow the persecutor bar to be applied. Moreover, before the bar is finally applied, the applicant must have fair notice and opportunity to show that DHS has not met its burden. If DHS does meet its burden, then the burden shifts to the applicant to show that her assistance in persecution was the result of duress. If the applicant cannot meet that burden, then and only then can the adjudicator determine that the bar applies.

In the pages that follow, I will explore how the Board arrived at the current set of lax procedures, in an effort to provide a clear path forward for future litigants to advance a more protective procedural framework in the persecutor bar context. In the first section, I will look at the historical development of the persecutor bar, including the recent analysis provided by the BIA in Matter of Negusie. ${ }^{37}$ I will also explore how the BIA's past use of the generic-relief regulation has been used to improperly force putative refugees to prove in the abstract that they did not assist in persecution. ${ }^{38}$ In the second section, I will analyze the background of the generic-relief regulation and how its current interpretation as applied to the persecutor bar is unacceptable in light of the statute and the gravity that application of the bar carries for those otherwise meeting the refugee definition. ${ }^{39}$ With that foundation laid, I will proceed with the project of constructing a more protective procedural framework. In section three, I discuss the necessary substantive components of "assistance or participation" in persecution. ${ }^{40}$ And in the final section, I discuss the minimum procedural safeguards established in similar contexts to serve as a baseline for the necessary procedural safeguards in the persecutor

thursday/2019/02/13/f162e514-2fla-11e9-813a-0ab2f17e305b_story.html?utm_term=.05124a31342a. As this article goes to print, Barr has yet to issue a decision. While the outcome remains to be seen, Matter of Negusie is likely to be the subject of litigation for years to come.

37. See infra Section I.A.

38. See infra Section I.B.

39. See infra Section II.

40. See infra Section III. 
bar context. ${ }^{41}$ Within this section, I address the proper allocation of burdens of proof, the nature of that burden, and the necessary due process protections of notice and opportunity to be heard. ${ }^{42}$

\section{Recent Historical Context and Evolution Of The Interpretation And Application Of The Persecutor Bar}

\section{A. From Fedorenko To Negusie: The Duress Question}

The INA bars asylum and withholding of removal for those "the Attorney General determines" or "decides" have "ordered, incited, assisted, or otherwise participated in the persecution of any person on account of race, religion, nationality, membership in a particular social group, or political opinion." ${ }^{43}$ Likewise, Congress has categorically excluded from the definition of a refugee anyone engaged in persecution. ${ }^{44}$ Collectively, these provisions are referred to as the "persecutor bar." 45

In U.S. law, the persecutor bar can be traced back to the 1980 Refugee Act, ${ }^{46}$ which is itself linked back further to the 1951 Refugee Convention ${ }^{47}$ and 1967 Protocol. ${ }^{48}$ The Refugee Convention was crafted with "the memory of the [post-World War II] trials of major war criminals ... still very much alive. ${ }^{, 49}$ As such, the drafters were careful to include an exclusion to refugee

41. See infra Section IV.

42. See id.

43. 8 U.S.C. $\$ \S 1158($ b)(2)(A)(i); 1231(b)(3) (emphasis added). The asylum version of the persecutor bar is virtually identical to that of the withholding statute. The asylum statute uses the word "determined," while the withholding statute uses the synonym "decide."

44. 8 U.S.C. $\$ 1101(\mathrm{a})(42)$.

45. While the focus of this article is the persecutor bar in the context of applications for withholding of removal and asylum, a version of the bar is also contained within other areas of the INA and functions as an absolute bar to several forms of relief. See e.g., 8 U.S.C. $\$ 1231(\mathrm{~b})(3)(\mathrm{B})(\mathrm{i})$ (withholding); 8 U.S.C. $\S 1158(\mathrm{~b})(2)(\mathrm{A})(\mathrm{i})$ (asylum); 8 U.S.C. $\$ 1229 \mathrm{~b}(\mathrm{c})(5)$ (lawful permanent resident (LPR) and non-LPR cancellation of removal); 8 U.S.C. $\$ 1254 \mathrm{a}(\mathrm{c})(2)$ (b)(ii) (temporary protected status); 8 C.F.R. $\$ 1240.66(\mathrm{a})$ (NACARA); 8 U.S.C. $\S 1182(a)(3)$ (E) (grounds of inadmissibility); 8 U.S.C. $\S 1227(a)(4)$ (D) (grounds of removability). Additionally, since admissibility is a requirement for adjustment of status, the persecutor bar can also render one ineligible for permanent residence, and thereby act as a bar to citizenship as well. See 8 U.S.C. $\$ \S 1255(\mathrm{a}) ; 1427$.

46. Pub. L. No. $96-212$ (1980), 94 Stat. 102.

47. 1951 Convention Relating to the Status of Refugees, July 28, 2951, 19 U.S.T. 6259,189 U.N.T.S. 150 (hereinafter Convention).

48. UN Protocol Relating to the Status of Refugees, January 31, 1967, 19 U.S.T. 6224, 606 U.N.T.S. 267 (hereinafter Protocol). The United States acceded to Articles 2 through 34 of the Convention when it signed on to the Protocol in 1968. See INS v. Stevic, 467 U.S. 407, 416 (1984); INS v. Cardoza-Fonseca, 480 U.S. 421,429 (1987). The withholding of removal provision of INA $\$ 241$ (b)(3) (formerly INA section $243(\mathrm{~h})$ ), which prohibits the removal of a noncitizen to a country where "life or freedom would be threatened" because of a protected ground, also corresponds to the Convention. See Convention, art. 33.1 (discussing the signatory-states' obligation to not expel or return ('refouler') a refugee where is his life or freedom would be threatened). The persecutor bar to withholding relief was added by the 1978 Holtzman Amendment. See H.R. REP. NO. 95-1452, at 7 (1978) (noting that "crimes against humanity" include "persecution on political, racial or religious grounds").

49. ANKER, supra note 6 , \& 6:3 (citing Guy S. GOOdwin-Gill \& JANE MCAdAM, THE RefugeE IN INTERNATIONAL LAW 167 (2007)). 
protection, in Article $1 \mathrm{~F}(\mathrm{a})$, by barring relief to those who "committed a crime against peace, a war crime, or a crime against humanity." ${ }^{50}$ While U.S. law did not utilize the Convention's exact language in this respect, the U.S. Supreme Court has long recognized congressional intent to construe the asylum and refugee provisions consistently with the Convention. ${ }^{51}$ Indeed, the House Judiciary Committee Report accompanying the Refugee Act's persecutor bar explicitly stated that the bar was intended to be "consistent with the U.N. Convention (which excludes those who, inter alia, committed a crime against peace, a war crime, or a crime against humanity). ${ }^{, 52}$

Yet, despite the clear congressional intent to look to the Convention for guidance in understanding the scope of the persecutor bar, early decisions by the Board failed to take this approach. ${ }^{53}$ Instead, the Board rooted its persecutor bar analysis in a prior Supreme Court case, Fedorenko v. United States. ${ }^{54}$ In Fedorenko, the Supreme Court analyzed whether the Displaced Persons Act of 1948 (DPA $)^{55}$ - a distinct World War II era statute that prohibited the issuance of visas to persons who assisted in Nazi persecution - contained an involuntariness exception. ${ }^{56}$ Utilizing "traditional principles of statutory construction," the Court concluded that no such exception existed. ${ }^{57}$ The Court grounded its analysis within the unique structure of the DPA, with its disparate inclusion and exclusion of the word voluntary in two related bars. ${ }^{58}$ The Court thus concluded that the "deliberate omission of the word 'voluntary' from [the DPA's persecutor provision] compel[led] the conclusion that the statute made all those who assisted in the persecution of civilians ineligible for visas" regardless of whether their actions were voluntary or not. ${ }^{59}$

\section{Id.}

51. Cardoza-Fonseca, 480 U.S. at 437 (In noting the link between INA $\$ 208$ (a) and Article 34 of the Convention, the Court observed that there were "many statements indicating Congress' intent that the new statutory definition of 'refugee' be interpreted in conformance with the Protocol's definition."); INS v. Aguirre-Aguirre, 526 U.S. 421, 427 (1999) (recognizing that the "withholding provision ... parallels [the Convention's] Article 33").

52. ANKER, supra note 6, at § 6:4; H.R. REP. No. 96-608 at 9-10 (1979) ("All witnesses appearing before the Committee strongly endorsed the new [refugee] definition, which will finally bring United States law into conformity with the internationally-accepted definition of the term 'refugee' set forth in the ... Convention and the Protocol...."); id. at 18 (explaining that the statutory bars within the Refugee Act "are those provided in the Convention.").

53. See e.g., In re Laipenieks, 18 I. \& N. Dec. 433, 434-36 (B.I.A. 1983), rev'd, Laipenieks v. INS, 750 F.2d 1427 (9th Cir. 1985); In re Fedorenko, 19 I. \& N. Dec. 57 (B.I.A. 1984); In re RodriguezMajano, 19 I. \& N. Dec. 811 (B.I.A. 1988).

54. Fedorenko v. United States, 449 U.S. 490, 512 (1981).

55. Displaced Persons Act of 1948, 62 Stat. 1009 (1948).

56. Fedorenko, 449 U.S. at 512.

57. Id.

58. Id.

59. Id. The DPA provided a bar both for anyone who "assisted the enemy in persecuting civil populations of countries" and anyone who "voluntarily assisted the enemy forces since the outbreak of the second world war." Id. Given that Congress intentionally excluded the word voluntary when discussing the DPA's persecutor bar, the Court concluded that "all those who assisted in the persecution of civilians" would be barred regardless of whether that assistance was voluntary or not. Id. 
Shortly thereafter, in Laipenieks, ${ }^{60}$ the Board extended Fedorenko's holding to the Holtzman Amendment, a ground of deportability for those who "ordered, incited, assisted, or otherwise participated in persecution" on account of a protected characteristic. ${ }^{61}$ However, in addition to holding that there was no voluntariness exception in the Holtzman Amendment, the Board went a step further by stating that a person's "motivation and intent are irrelevant" 62 and that instead the "objective effect" of the person's actions "is controlling." $"$ The Board later acknowledged that Laipenieks could result in "harsh or inequitable" outcomes, but insisted that the matter was foreclosed by Congress. ${ }^{64}$ When the voluntariness question arose with regard to the Refugee Act's persecutor bar, the Board in Rodriguez-Majano treated Fedorenko as dispositive, holding that the Refugee Act's persecutor bar had no such exception, notwithstanding the material structural differences between the DPA and the Refugee Act. ${ }^{65}$

For the next two decades, the Board continued to apply its objective effects test, ruling that there was no duress exception to the persecutor bar. ${ }^{66}$ However, this line of cases was brought to a halt in 2009, when the Supreme Court intervened in Negusie v. Holder. ${ }^{67}$ In that case, the Eritrean government had incarcerated and tortured Mr. Negusie for two years before forcing him to serve as an armed guard at a prison camp where others like him were persecuted on account of a protected characteristic. ${ }^{68}$ The Board, applying Rodriguez-Majano, held that voluntariness and duress were irrelevant in assessing the extent to which Negusie's conduct constituted "assistance or participation in persecution," an interpretation it claimed was compelled by Fedorenko. ${ }^{69}$

On appeal, however, the Supreme Court disagreed, explaining that Fedorenko was rooted in the distinct provisions of the DPA, ${ }^{70}$ and therefore did not bind the Board in its analysis of the Refugee Act. ${ }^{71}$ The Supreme Court found that the provisions of the DPA at issue in Fedorenko differed from the Refugee Act's persecutor bar both textually and in its historical purpose, and that the BIA had therefore erred in assuming Fedorenko controlled its interpretation of the persecutor bar in the Refugee Act. ${ }^{72}$ In remanding

60. See e.g., In re Laipenieks, 18 I. \& N. Dec. 433, 434-36 (B.I.A. 1983), rev'd, Laipenieks v. INS, 750 F.2d 1427 ( 9 th Cir. 1985).

61. Id.

62. Id. at 465 .

63. Id.

64. In re Fedorenko, 19 I. \& N. Dec. 57 (B.I.A. 1984).

65. In re Rodriguez-Majano, 19 I. \& N. Dec. 811 (B.I.A. 1988) (holding that "participation or assistance of an alien in persecution need not be of his own volition to bar him from relief").

66. See generally Evans, supra note 25.

67. Negusie v. Holder, 555 U.S. 511 (2009).

68. Id. at 515 .

69. Id. at 519 (citing Fedorenko, 449 U.S. 490, 512 (1981)).

70. Displaced Persons Act of 1948, ch. 647, 62 Stat. 1009 (1948)

71. Negusie, 555 U.S. at 516-23.

72. Id. 
Negusie, the Supreme Court, applying the principles of Chevron, U.S.A. v. Nat'l Resources Defense Council, ${ }^{73}$ and S.E.C. v. Chenery, ${ }^{74}$ found that the refugee statute was ambiguous on the question of duress and left it to the agency to decide the scope of the persecutor bar in the first instance. ${ }^{75}$

Justice Kennedy's majority opinion reminded the Board that " $[\mathrm{t}] \mathrm{he}$ persecutor bar . . . was enacted as part of the Refugee Act of 1980 [and] one of Congress' primary purposes in passing the Refugee Act was to implement the principles agreed to in the 1967 Protocol Relating to the Status of Refugees. ${ }^{166}$ The Supreme Court thus invited the agency to engage in a process whereby an "interpretation of the statutory meaning of 'persecution' may be explained by a more comprehensive definition, one designed to elaborate on the term in anticipation of a wide range of potential conduct.",77

While the Supreme Court remanded Negusie in 2009, it was not until 2016 that the BIA began to seriously reconsider the matter. ${ }^{78}$ On August 8, 2016 the BIA issued Amicus Invitation No. $16-08-08,{ }^{79}$ which posed two question: First, does "an involuntariness or duress exception exist to limit the application of the persecutor bar in sections 208(b)(2)(A)(i) and 241(b)(3)(B)(i) of the Immigration and Nationality Act, 8 U.S.C. $\S \S 1158(b)(2)(A)(i), 1231$ (b) (3)(B)(i). ${ }^{" 80}$ Second, "[a]ssuming it is necessary to acknowledge a duress exception to the persecutor bar, what ought to be the standards (including relevant burdens of proof) to determine if an applicant for asylum qualifies for such an exception?" 81 Prior to issuing the amicus invitation, the BIA also had ordered supplemental briefs from Mr. Negusie and DHS. ${ }^{82}$

In its brief, DHS (under the Obama administration) initially agreed that a duress defense is appropriate and asked the BIA, "[i]n addition to issuing substantive duress elements ... [, to] provide guidance about the procedural application of the elements." ${ }^{\circ 3}$ DHS urged that when interpreting the persecutor bar the BIA should impose "procedural safeguards" that effectively focus the bar on "bona fide human rights violators," beginning with a requirement that an IJ first "determine whether persecution occurred." ${ }^{4}$ According to DHS, only after an IJ rules that the identified conduct meets the legal test

\footnotetext{
73. 467 U.S. 837 (1984).

74. 318 U.S. 80 (1943).

75. Negusie, 555 U.S. 519-23 ("Having concluded that the BIA has not yet exercised its Chevron discretion to interpret the statute in question, the proper course, except in rare circumstances, is to remand to the agency for additional investigation or explanation.") (internal quotations omitted) (citing Gonzales v. Thomas, 547 U.S. 183, $186(2006)$ ).

76. Id. at 520 (citations and quotations omitted).

77. Id. at 524 .

78. See generally Evans, supra note 25 .

79. See Amicus Invitation, supra note 16

80. Id.

81. Id.

82. See Evans, supra note 25. DHS filed its supplemental brief on April 20, 2016. It is on file with the author.

83. DHS Supplemental Brief at 18. (emphasis added).

84. Id. at $11-12,21$.
} 
for "persecution" can she properly evaluate "whether the applicant's acts could constitute assistance" in that persecution. Sequentially, any analysis of duress will follow these prior two steps. ${ }^{85}$ However, on April 26, 2017, under the Trump Administration, DHS reversed course and filed a substituted supplemental brief withdrawing from the earlier position advanced in DHS's 2016 supplemental brief. ${ }^{86}$ This move triggered a new round of amicus briefing and more waiting. ${ }^{87}$

On June 28,2018 , after nearly three decades of litigation on the duress question, the Board finally concluded that the persecutor bar did indeed have a duress defense, albeit a narrow one ${ }^{88}$ In reaching this conclusion in Matter of Negusie, the Board began by anchoring its analysis in the international law materials from which U.S. refugee law emerged. ${ }^{89}$ The Board explained that "[i]t is well established that Congress enacted the Refugee Act to bring the United States law into conformity with the Convention and Protocol." 90 Turning then to the parallel exclusionary clause of the Convention, the Board concluded that "Congress intended ... the persecutor bar [to] be interpreted in a way that not only comports with our obligations under Article $1 \mathrm{~F}(\mathrm{a}) \ldots$, but also reflects the international understanding of those obligations." ${ }^{11}$ The BIA found that "the overriding purpose of . . A Article $1 F(a)$. . is to protect the 'integrity of the international refugee regime' by ensuring that those who are undeserving of international refugee protection, in particular war criminals, cannot benefits under the Convention." ${ }^{92}$ In following this line of reasoning, the Board took the lead of Professors Kate Evans and Sabrineh Ardalan ${ }^{93}$ by looking to the trials of war criminals in Nuremberg for guidance. ${ }^{94}$ In those proceedings, the "International Military Tribunal recognized that persons could not be held individually responsible for executing an order unless they had the ability to make a moral choice." 95 Accordingly, the Tribunals recognized a "duress defense to war crimes," reasoning that "[n]o court will punish a man who, with a loaded pistol to his head, is compelled to pull a lethal lever." ${ }^{\circ 6}$ Given Article $1 \mathrm{~F}(\mathrm{a})$ 's reference to "war crimes"-

\footnotetext{
85. Id. at 21 .

86. Brief on file with the author. While DHS asserted in its new brief there should be no duress exception to the persecutor bar, it still implicitly conceded that clarity is needed related to the "legal framework" for applying the persecutor bar. See DHS Substituted Supplemental Brief, April 26, 2017, at 18 (citing Matter of A-G-G-, 25 I. \& N. Dec. 486, 501-03 (B.I.A. 2011), as the "ostensible legal framework" for a persecutor bar analysis, but questioning how it would work in practice).

87. See supra note 25.

88. Matter of Negusie, 27 I. \& N. Dec. 347 (B.I.A. 2018).

89. Id. at 353-60.

90. Id. at 353 .

91. Id. at 356

92. Id. at 357 (emphasis added) (citing James C. Hathaway, The Michigan Guidelines on the Exclusion of International Criminals, 35 MiCH. J. INT'L L. 3, 7 (2013)).

93. Professors Evans and Ardalan led the team that authored the International Law Scholars amicus brief before the Board in Matter of Negusie. See Evans, supra note 25.

94. Matter of Negusie, 27 I. \& N. Dec. at 357; see also Evans, supra note 7, at 473.

95. Matter of Negusie, 27 I. \& N. Dec. at 357.

96. Id. at 358 .
} 
term historically embedded with a duress defense-and the clear Congressional intent to construe the Refugee Act consistently with the Convention (including Article $1 \mathrm{~F}(\mathrm{a})$ ), the Board readily concluded that the persecutor bar to asylum and withholding in U.S. law also carried over this "principle of duress.","97

In elaborating on the contours of this defense, the Board created a five-part test, requiring at a minimum that the applicant "establish by a preponderance of the evidence that he (1) acted under an imminent threat of death or serious bodily injury to himself or others; (2) reasonably believed that the threatened harm would be carried out unless he acted or refrained from acting; (3) had no reasonable opportunity to escape or otherwise frustrate the threat; (4) did not place himself in a situation in which he knew or reasonably should have known that he would likely be forced to act or refrain from acting; and (5) knew or reasonably should have known that the harm he inflicted was not greater than the threatened harm to himself or others." 98

Proceeding then to the procedural framework, the Board explained that the "adjudicator should first determine whether the applicant is otherwise eligible for asylum or withholding of removal." 99 By beginning the analysis with this requirement, the question of duress will only arise in cases of individuals who have already been found to otherwise meet the definition of a refugee on a record that has been fully developed. If a person is not eligible for refugee protection, then the adjudicator need not address the persecutor bar. Next, before reaching the question of duress, the Board discussed the meaning of the terms "assisted or otherwise participated in persecution." 100 The Board explains that "[a]s an initial point. .., the term 'persecution' in the persecutor bar" context carries "the same meaning as it does in the context of determining ... eligibility for asylum." 101 Thus, the Board reaffirmed that implicit within the persecutor bar analysis are the requirements that (1) there be an act of harm sufficiently severe to constitute persecution and (2) that that harm be inflicted on account of a protected characteristic. ${ }^{102}$ Additionally, to sustain a finding of assistance or participation in persecution, (3) there must be a connection, or " "nexus[,] between the [applicant's] role, acts, or inaction," on the one hand, and persecution, on the other; and (4) the applicant must have had "scienter," i.e., " "prior or contemporaneous knowledge' of the persecution." 103 Then, utilizing the generic-relief regulation, 8 C.F.R. $\$ 1240.8(\mathrm{~d}),{ }^{104}$ the Board concludes that once "DHS [has] satisfied its initial burden of proving that the [applicant] assisted or otherwise participated in persecution," the

\footnotetext{
97. Id. at 359 .

98. Id. at 363 .

99. Id. at 366 .

100. Id.

101. Id.

102. Id.

103. Id.

104. See supra note 27.
} 
"burden shifts to the [applicant] to show by a preponderance of the evidence that the persecutor bar does not apply, either because he did not engage in persecution or because he acted under duress." ${ }^{105}$ The Board sets DHS's initial burden on the above points as a requirement to "offer sufficient prima facie evidence" that the applicant "incited, assisted, or otherwise participated in persecution." 106

$$
\text { **** * * }
$$

The decision in Matter of Negusie was undoubtedly a triumph for refugees coerced into involvement with persecution. It represented a distinct break from past decisions that cruelly barred from relief refugees-such as child soldiers - forced to harm family or friends. It also brought U.S. law more closely in line with international interpretations, a development worthy of celebration. ${ }^{107}$ However, while some of the procedures adopted in the decision were certainly a step in the right direction, there is more work to be done to advance protective procedural safeguards in this context. Specifically, Matter of Negusie contained residual language from earlier problematic decisions such that the Board did not necessarily lay to rest what I call the "laxprocedure" approach. ${ }^{108}$ Rather, the Board in Negusie doubled down and reaffirmed that "the relevant inquiry under 8 C.F.R. $\& 1240.8(d)$ is whether the evidence indicates that the grounds for mandatory denial ... may apply" to the applicant "so that he then has the burden to show that they do not apply." 109 Prior to Matter of Negusie, the Board had explained in M-B-C- that "[i]n using the terms 'indicates' and 'may apply' together," the regulation "does not create an onerous standard and necessarily means a showing less than the preponderance of the evidence." 110 Rather than distancing itself from $M-B-C-$, the Board in Matter of Negusie cites it approvingly. ${ }^{111}$ As such, there still exists a risk that a refugee may be forced to prove a negative based upon a small amount of evidence related to her alleged involvement in persecution. Additionally, given that Matter of Negusie is currently being reviewed, what gains were achieved in that decision may well be rolled back.

105. Matter of Negusie, 27 I. \& N. Dec. at 367.

106. Id. at 366 .

107. The decision also contained a fiery dissent that likely drew the attention of Attorney General Sessions, who announced on October 18, 2018, that he intended to review the decision. The positive aspects of Negusie were hard-fought, soundly reasoned, and should withstand even the most withering scrutiny on the duress question. However, the battle is far from over. The case remains pending as this article goes to print.

108. See supra note 26-32 and accompanying text. Additionally, following Negusie there remains an unexplained tension between some of the procedures adopted in Negusie that undoubtedly advance the case for procedural safeguards and the holding and reasoning of $M a t t e r$ of $M-B-C$-, that unequivocally jeopardize refugees accused of assisting in persecution. These tensions are discussed below in Section I.B.

109. Matter of Negusie, 27 I. \& N. Dec. at 367.

110. Matter of M-B-C-, 27 I. \& N. Dec. 31, 36-37 (B.I.A. 2017) (emphasis added). Matter of $M-B-C$ is analyzed in greater detail in Section I.B.

111. Matter of Negusie, 27 I. \& N. Dec. at 366-67. 
In the next section, I will explore the cases leading up to Negusie that adopted the "lax-procedure approach" at which this article takes aim.

\section{B. Past Expansive Application Of The Persecutor Bar Through Lax Procedures}

In the absence of guidance regarding the question of duress, much of the persecutor bar litigation prior to Matter of Negusie had focused on the meaning of the term "assistance or participation in persecution," and to a lesser degree, the procedure for applying the bar. During the course of this litigation, the BIA adopted an approach incorporating the use of the generic-relief regulatory framework ${ }^{112}$ to effectively place the burden of proof on the putative refugee to disprove involvement in persecution based on little more than speculation that she might have been involved in persecution.

The federal regulation at issue provides that "[i]f the evidence indicates that one or more of the grounds for mandatory denial of the application for relief may apply, the alien shall have the burden of proving by a preponderance of the evidence that such grounds do not apply." 113 In several unpublished decisions described below, the BIA used this regulation in the persecutor bar context and found it sufficient to apply the bar in cases where the evidence was simply the applicant's concession of past membership in a group with a bad human rights record. ${ }^{114}$ In this section, I will trace the development of this "lax-procedure approach" from unpublished to published Board decisions.

In Mazariegos Hernandez v. Holder,${ }^{115}$ the IJ found the Applicant credible over the strong objections of DHS. However, the IJ held that the NACARA persecutor bar applied by agreeing with DHS's framing of the case through the lens of the generic-relief regulation, 8 C.F.R. $\S 1240.8(\mathrm{~d}){ }^{1{ }^{16}}$ The Applicant's "involvement" in persecution in that case consisted only of his coerced two years of service in the Guatemalan military - a group known for its human rights abuses - and his deployment to an area of the country where he twice saw men that he believed were guerrillas tied to a tree in the camp. He was later ordered to send men under his command to dig graves, though

112. Id.

113. See 8 C.F.R. $\$ 1240.8$ (d) (emphasis added).

114. Both of the unpublished cases analyzed below involved the persecutor bar to relief under the Nicaraguan Adjustment And Central American Relief Act ("NACARA"), 111 Stat. 2160. NACARA "allows ABC class members to seek relief under conditions approximating pre-IIRIRA suspension of deportation," a repealed form of relief for certain noncitizens with long-term presence in the U.S. See Hernandez v. Napolitano, No. 8:13CV113, 2013 WL 6662861, at *2 (D. Neb. Dec. 17, 2013). The "ABC settlement class was broadly defined as 'Guatemalans in the United States as of October 1, 1990' and "Salvadorans in the United States as of September 19, 1990." Id. While the persecutor bar to NACARA is worded the same as the bar to asylum and withholding, the consequences of application of the bar varies considerably, ranging from a simple deportation in the case of many NACARA cases, to a probable death sentence in the case of withholding of removal.

115. No. 13-1793 (8th Cir. 2014).

116. See Matter of Mazariegos Hernandez et al., immigration judge decision (Jack $\mathbf{L}$. Anderson), Omaha, NE (July 27, 2011) (on file with the author). 
he did not know for whom. The IJ found credible his testimony that he never personally captured or harmed (or assisted in the capture or harming of) any guerrillas. However, the Court found that because DHS presented evidence that he may have assisted in persecution (i.e., the graves may have been for the disappeared guerrillas tied to the tree), the IJ shifted the burden and found that the applicant failed to prove he did not engage in persecution. The BIA affirmed in an unpublished decision in 2013. ${ }^{117}$

Similarly, in Cortez-Gaitan v. Lynch, ${ }^{118}$ the Applicant was also seeking NACARA relief, but was found ineligible because of the persecutor bar. In that case, the IJ found that because Mr. Cortez-Gaitan was a soldier who had guarded guerillas that had been captured and subjected to unspecified "poor treatment," the government met its burden of establishing that $\mathrm{Mr}$. Cortez-Gaitan's actions "may have constituted assistance in persecution."119 The IJ then found implausible Mr. Cortez-Gaitan's denials of any actual involvement in persecution. As such, the IJ applied the bar because Mr. Cortez-Gaitan "did not meet his burden of proof ... [to] establish[] by a preponderance of the evidence that he is not barred from relief." 120 The BIA agreed with the IJ in an unpublished decision in 2016. ${ }^{121}$

Then, in 2017 the Board issued two precedent decisions, Matter of J.M. Alvarado and Matter of $M-B-C$-, building off of its prior unpublished decisions to solidify aspects of this lax-procedure approach. ${ }^{122}$ While these Board decisions were issued on records decidedly worse than the unpublished cases described above, the reasoning employed by the Board in those cases may have far-reaching effects by expanding application of the persecutor bar through the use of slipshod procedures.

In Matter of J.M. Alvarado, ${ }^{123}$ the Board ostensibly placed the initial burden of proof on the applicant in considering the applicability of the persecutor bar again in the context of a NACARA application. ${ }^{124}$ It began its analysis by stating that " $[\mathrm{t}] \mathrm{o}$ establish eligibility for special rule cancellation of removal under ... NACARA, the respondent must show that he is not barred from relief because he ordered, incited, assisted, or otherwise participated in the persecution of an individual because of the individual's race, religion, nationality, membership in a particular social group, or political opinion." ${ }^{25}$ While it is unclear whether the Board intended to place the initial burden to prove a

\footnotetext{
117. Matter of Mazariegos Hernandez et al., BIA decision (March 7, 2013) (on file with the author).

118. No. 16-1651 (8th Cir. 2016).

119. Matter of Cortez Gaitan et al., immigration judge decision (Jack L. Anderson), Omaha, NE (August 8, 2014) (on file with the author).

120. Id.

121. Matter of Cortez Gaitan et al., BIA decision (February 19, 2016) (on file with the author).

122. See Matter of J.M. Alvarado, 27 I. \& N, Dec. 27, 28 (B.I.A. 2017); Matter of M-B-C-, 27 I. \&

N. Dec. 31,38 (B.I.A. 2017).

123. 27 I. \& N. Dec. 27,28 (B.I.A. 2017)

124. Id.

125. Id. at 27 (emphasis added).
} 
negative on the applicant, ${ }^{126}$ in this case, a different burden may not have made a difference as there was significant evidence of assistance and participation in persecution. ${ }^{127}$ That said, this aspect of $J . M$. Alvarado represented a troubling move with regard to placing (or effectively placing) the initial burden of proof on the applicant in the persecutor bar context. While Matter of Negusie clarified that the initial burden of proof in the persecutor bar context is on DHS, it did not address or otherwise explain how J.M. Alvarado fits into that analysis. At a minimum, the two decisions now stand in an unexplained tension with one another. ${ }^{128}$

Even more concerning, however, was the reasoning employed by the Board in Matter of $M-B-C-.{ }^{129}$ There, the Board focused its analysis on interpreting the meaning of the extrajudicial killing ground of inadmissibility. ${ }^{130}$ As in J.M. Alvarado, the Board began by pointing out that a "respondent has the burden to establish that he satisfies the applicable eligibility requirements for his applications for relief from removal." 131 The Board also stated that "under 8 C.F.R. $§ 1240.8(\mathrm{~d})$ " the relevant inquiry "is whether the evidence indicates that the ground[] for mandatory denial in section[] 212(a)(3)(E) ... of the Act may apply to him so that he then has the burden to show that [it does] not apply."132 In expounding upon the meaning of this regulation, the Board explains that "[i]n using the terms 'indicates' and 'may apply'

126. Later in the decision - after recognizing the uncontested facts of respondent's involvement in persecution-the Board stated that the "respondent does not dispute that he bears the burden to disprove that he was engaged in persecution." $I d$. at " 28 n.2 (citing Castañeda-Castillo v. Gonzales, 488 F.3d 17, $21 \mathrm{n} .3$ (noting that once DHS introduces evidence of an applicant's participation in persecution, he has the burden to disprove that he engaged in persecution); Matter of R-S-H-, 23 I. \& N. Dec. 629,640 (B.I.A. 2003) (stating that "[w]here the evidence indicates that one or more of the grounds for mandatory denial of an application for relief may apply, the alien has the burden of proving by a preponderance of the evidence that such grounds do not apply" in the danger to security bar context)). The BIA's reasoning in footnote two is in tension with its earlier pronouncement that the initial burden to disprove the persecutor bar is on the applicant. J.M. Alvarado is also in tension with Negusie, which clearly provided that DHS bears the initial burden of proof on the persecutor bar. See infra note 130 .

127. Indeed, the uncontroverted record evidence indicated that the respondent-who served in the Salvadoran National Guard from 1981 to 1984 captured a detainee and stood guard while "his superiors severely mistreated" the detainee by "placing needles under his fingernails and that such acts were based on the victim's political opinion." Matter of J.M. Alvarado, 27 I. \& N. Dec. at 28 . The Board noted that "[t] he respondent [did] not contest that he assisted his superiors' actions and that their acts were committed on account of the victim's political opinion;" nor did "he assert that" he lacked "prior or contemporaneous knowledge of his superiors' persecutory acts." Id. (internal quotations omitted).

128. Compare Matter of Negusie, 27 I. \& N. Dec. 366, with Matter of J.M. Alvarado, 27 I. \& N. Dec. at 28 .

129. 27 I. \& N. Dec. 31,38 (B.I.A. 2017)

130. Id. at 33 (discussing the meaning of section 212 (a)(3)(E)(iii)(II), which renders inadmissible any noncitizen "who outside the United States, has committed, ordered, incited, assisted, or otherwise participated in the commission of ... under color of law of any foreign nation, any extrajudicial killing.") (emphasis added). The extrajudicial killing bar has similar language to the persecutor bar, but it is a separate statutory scheme. See $i d ; ; 8$ U.S.C. $\$ 1231$ (b)(3)(B)(i) (withholding); 8 U.S.C. $\$ 1158($ b)(2)(A)(i) (asylum).

131. Matter of $M-B-C-, 27$ I. \& N. Dec. at 33 (citing 8 U.S.C. $\$ 1229 \mathrm{a}(\mathrm{c})(4)(\mathrm{A})(2012)$ ("An alien applying for relief or protection from removal has the burden of proof to establish that the alien satisfies the applicable eligibility requirements; and with respect to any form of relief that is granted in the exercise of discretion, that the alien merits a favorable exercise of discretion").

132. Id. at 36 . 
together," the regulation "does not create an onerous standard and necessarily means a showing less than the preponderance of the evidence." ${ }^{133}$ Then, taking the analysis one step further, the Board treats the phrase "the bar may apply" as being equivalent to saying the applicant may have "committed, ordered, incited, assisted or otherwise participated" in an extrajudicial killing. ${ }^{134}$ Finally, and without any independent analysis of the Refugee Actwith its distinct roots in the Refugee Convention and the Protocol-the Board injects all of its reasoning specific to the extrajudicial killing bar into the asylum/withholding persecutor bar statutes, apparently having forgotten the lessons learned in Negusie. ${ }^{135}$ The Board tersely reasons that "[b]ased on the above discussion, we conclude that the evidence presented is sufficient to indicate that the respondent may have assisted or otherwise participated in this persecution and that his incredible testimony is insufficient to prove by a preponderance of the evidence that he did not." ${ }^{136}$ Given the disparate structures of these two bars, it was error to export the analysis of 212(a)(3)(E) (i.e., a ground of inadmissibility, where the provision functions merely to prevent admission) to the persecutor bar (i.e., an absolute bar to withholding that authorizes one's removal to a country where she faces a clear probability of being persecuted). ${ }^{137}$

$$
* * * *
$$

In each of the cases discussed in this section, the BIA's application of the generic-relief regulation ${ }^{138}$ to the persecutor bar reveals that it does not require actual assistance or participation in persecution to apply the bar. Rather, the most minimal showing -including mere evidence of membership in an organization with a poor human rights record-is treated as sufficient to shift the burden and trigger the applicant's responsibility to establish the bar does not apply. As discussed below, this approach upsets decades of precedent and is irreconcilable with the statute. ${ }^{139}$ Because this lax-procedure

133. Id. at 36-37 (emphasis added).

134. Id. at 37. At first blush, equating "the bar may apply" with "the applicant may have assisted in persecution" appears sound. However, as explained further below, there are four distinct and necessary elements to the persecutor bar, and the applicant should be given notice, opportunity to respond, and a chance to show the conduct was the result of duress. See infra Section III-IV. Frequently DHS offers no evidence related to nexus, severity of harm, or culpable knowledge. As such, offering some evidence of just one element (e.g., the applicant had some involvement in an activity where persecution occurred) is not at all the same as showing possible application of the bar itself.

135. Matter of $M-B-C-, 27$ I. \& N. Dec. at 37. See also infra Section IV.A.2.

136. Matter of $M-B-C-, 27$ I. \& N. Dec. at 38 . Like the facts in $J . M$. Alvarado, the facts of $M-B-C$ were more incriminating than those discussed above in unpublished decisions. The Board noted in $M-B-C$ - that "DHS ... presented extensive evidence [including expert testimony] showing not only that the respondent was a member of military and police units that engaged in extrajudicial killings and genocide during the Bosnian War, but also that his service in those units correspond[ed] with the times and locations of extrajudicial killings and genocide." Id. at 39. However, the reasoning employed by $M-B-C$ and the rules it used to resolve the case are likely to further erode procedural protections needed by refugee charged with assistance or participation in persecution based upon much less evidence, even after Matter of Negusie.

137. See also infra Section IV.A.2.

138. 8 C.F.R. \$ $1240.8(\mathrm{~d})$.

139. See infra Section III.C. 
approach is rooted in generic-relief regulation and the Board's recent discussion of procedures in the persecutor bar context in Matter of Negusie did not disavow use of this regulation, I argue that is it now necessary to resist use of the generic-relief regulation in the persecutor bar context altogether. ${ }^{140}$

\section{The Need to Reformulate The Persecutor Bar's Procedural ANALYSIS}

As discussed in the previous section, the BIA has employed the generic regulatory framework of 8 C.F.R. $\S 1240.8$ (d) to effectively create-for withholding and asylum applicants - the burden to prove that they have not engaged in persecution based simply upon generalized allegations to the contrary. In this section, I look at the history of the regulation at issue, along with the related asylum-specific and withholding-specific regulations. I use the term "generic-relief regulation" to describe $1240.8(\mathrm{~d})$ because the regulation is not specific to asylum, withholding, or any other named form of relief, but simply applies generally to "application[s] for relief." Throughout this section, I juxtapose this generic-relief regulation with the regulations specific to asylum and withholding of removal (i.e., the "asylum-specific" and "withholding-specific" regulations) to show how the generic-relief regulatory scheme is at odds with the more specific asylum/withholding regulatory scheme.

Ultimately, my thesis in this section is that the generic-relief regulation should not be applied at all to claims for asylum and withholding of removal. Indeed, as currently interpreted and applied in Matter of $M-B-C$-, and not clearly repudiated by Matter of Negusie, the regulation is inconsistent with the statute, particularly in light of the grave consequences that the persecutor bar carries. Rejecting the generic-relief regulation - as it relates to the persecutor bar-is the approach I believe to be most harmonious with the statute, the asylum/withholding-specific regulations, the analogous regulatory frameworks applicable to similar asylum and withholding bars, and international law.

\section{A. Contrasting the Generic-Relief Regulations with the Regulations Specific to Applications for Asylum and Withholding}

The current generic-relief regulation states that " $[\mathrm{i}] \mathrm{f}$ the evidence indicates that" a bar to relief "may apply," the burden shifts to the applicant to prove it

140. One of the amicus briefs in Negusie invited the Board to reframe its use of 8 C.F.R. $\S 1240.8$ (d) in manner that would ensure robust procedural protections for refugees. See supra note 25 . However, as discussed above, the Board declined that invitation. In light of the deference accorded to an agency's interpretation of its own regulations, see Auer v. Robbins, 519 U.S. 452, 457, 461 (1997), the most likely successful path for continued advocacy on this issue will be in the form of resisting application of the regulation altogether in the persecutor bar context. 
does not. ${ }^{141}$ The key language in this regulation is "may apply." The regulation specific to asylum applications, however, makes no use of the words "may apply"142 and is completely silent on burden-shifting. ${ }^{143}$ Rather, the asylum-specific regulation provides simply that "[f] or applications filed on or after April 1, 1997, an applicant shall not qualify for asylum if ... [the persecutor bar] applies to the applicant." "Similarly, in the regulation specific to withholding of removal the words "may apply" are conspicuously absent as well. ${ }^{145}$ The withholding-specific regulation provides that "[i]f the evidence indicates the applicability of one or more of the grounds for denial of withholding enumerated in the Act, the applicant shall have the burden of proving by a preponderance of the evidence that such grounds do not apply."146 Neither the asylum-specific nor the withholding-specific regulations contemplate switching the burden to an applicant simply where the persecutor bar "may apply."147

The same is true if we turn to the asylum-specific regulation applicable to claims filed before April 1, 1997. That regulation also noticeably omits the words "may apply." 148 In the first section, the regulation provides that "[a]n immigration judge or asylum officer shall not grant asylum to any applicant ... if the [applicant] ... [o]rdered, incited, assisted, or otherwise participated

141. The regulation in whole provides that:

"The respondent shall have the burden of establishing that he or she is eligible for any requested benefit or privilege and that it should be granted in the exercise of discretion. If the evidence indicates that one or more of the grounds for mandatory denial of the application for relief may apply, the alien shall have the burden of proving by a preponderance of the evidence that such grounds do not apply."

8 C.F.R. $\S 1240.8$ (d) (emphasis added)

142. Compare 8 C.F.R. $\$ 208.13$ (b)(1), with 8 C.F.R. $\$ 208.13($ b)(2).

143. Compare 8 C.F.R. $\$ 1208.13$ (c)(1) (making no reference to burdens of proof related to grounds of denial for applications filed after April 1, 1997), with 8 C.F.R. $\$ 1208.13$ (c)(2) (stating for applications filed before April 1, 1997, that "[i]f the evidence indicates that one of the above grounds [of denial] apply to the applicant," then she "shall have the burden") (emphasis added). Indeed, there is no parallel to the generic burden-shifting scheme of 8 C.F.R. $\S 1240.8(\mathrm{~d})$ in the current regulations related to post-April 1, 1997 asylum filings.

144. 8 C.F.R. $\$ 208.13$ (c)(1) (emphasis added); 8 U.S.C. $\$ 1158(\mathrm{~b})(2)($ A)(iii) (An applicant is not eligible for asylum "if the Attorney General determines that ... [he or she] ordered, incited, assisted, or otherwise participated in the persecution of any person ...").

145. See 8 C.F.R. $\$ 1208.16(d)(2)$.

146. See 8 C.F.R. $\$ 1208.16$ (d)(2) (emphasis added). The current wording of the withholding regulation is consistent with its earliest version. In 1990, the withholding regulation provided that:

"(c)(2) An application for withholding of deportation shall be denied if:

(i) The alien ordered, incited, assisted, or otherwise participated in the persecution of any person on account of race, religion, nationality, membership in a particular social group, or political opinion;

(3) If the evidence indicates that one or more of the grounds for denial of withholding of deportation enumerated in paragraph (c)(2) of this section apply, the applicant shall have the burden of proving by a preponderance of the evidence that such grounds do not apply."

55 FR 30674-01 (July 27, 1990) (emphasis added).

147. Id.

148. Compare 8 C.F.R. $\$ 208.13($ b)(2)(i)(E), with 8 C.F.R. $\$ 1240.8(d)$. 
in the persecution of any person on account of" a protected characteristic. ${ }^{149}$ Then, with regard to burden-shifting, the regulation states that "[i]f the evidence indicates that one of the above grounds apply to the applicant, he or she shall have the burden of proving by a preponderance of the evidence that he or she did not so act." ${ }^{150}$ Again, in neither section does the regulation permit application of the bar, or shifting the burden to the applicant, merely where an applicant may have assisted or participated in persecution. ${ }^{151}$

The critical reader, however, may be unconvinced by the disparate use of the words "may apply," and like the Board, may suggest that the word "indicate" similarly reveals a low burden. ${ }^{152}$ Though not in the current asylum regulation, it is true that the word "indicate" is present in both the pre-1997 asylum regulation and the withholding regulation. ${ }^{153}$ However, in contrast to the Board's reasoning in $M-B-C$-, the word "indicate" does not per se entail a low burden. Rather, a number of dictionaries define "indicate" to mean to show, point, or make clear. ${ }^{154}$ While some definitions reveal that the term can also mean "to strongly suggest," even that understanding does not support a low-burden construction. ${ }^{155}$ Moreover, as described below, any acceptable understanding of the asylum/withholding regulations must be developed and viewed through the lens of the statute, international law, and analogous regulatory frameworks, which require more than just possible participation in persecution to apply the bar. ${ }^{156}$

But even looking beyond the asylum/withholding-specific regulations, there is an additional reason to not apply the generic-relief regulation in this context. The text of the generic-relief regulation, by its own terms, only applies to an "application for [discretionary] relief." ${ }^{157}$ However, it is wellestablished that withholding of removal is not discretionary ${ }^{158}$ and does not constitute "relief." 159 As such, not only are the two regulatory schemes at

149. 8 C.F.R. $\$ 208.13$ (b)(2)(i)(E) (emphasis added).

150. 8 C.F.R. $\$ 208.13$ (b)(2)(ii) (emphasis added).

151. Id.

152. See Matter of $M-B-C-, 27$ I. \& N. Dec. at 36.

153. Compare 8 C.F.R. $\S 208.13(\mathrm{c})(1)$, with 8 C.F.R. $\$ 208.13(\mathrm{~b})(2)(\mathrm{i})(\mathrm{E})$, and 8 C.F.R. $\$ 1208.16$ (d)(2).

154. See Indicate, CAMBRIDGE ENGLISH DICTIONARY, https://dictionary.cambridge.org/us/ dictionary/english/indicate ("to show..., or to make something clear); Indicate, MERRIAM-WeBSTER DICTIONARY, https://www.merriam-webster.com/dictionary/indicate ("to point out").

155. See Indicate, OXFORD ENGLISH DictionARY, https://en.oxforddictionaries.com/definition/ indicate (to "[p]oint out; show" or "strongly suggest").

156. See infra Section IV.B.

157. 8 C.F.R. $\$ 1240.8(\mathrm{~d})$.

158. See Ali v. Ashcroft, 395 F.3d 722, 730 (7th Cir. 2005) (Withholding "is not discretionary. If an alien meets the statutory criteria, the Attorney General must withhold removal.") (citing I.N.S. v. Aguirre-Aguirre, 526 U.S. 415, 420 (1999)); Matter of I-S- \& C-S-, 24 I. \& N. Dec. 432, 434 (B.I.A. 2008) ("We note ... that a grant of withholding of removal is not discretionary.").

159. See Ramirez-Mejia v. Lynch, 794 F.3d 485, 489 (5th Cir. 2015) (recognizing that withholding of removal is a form of protection, not "relief"); Regulations Concerning the Convention Against Torture, 64 Fed. Reg. 8478 (February 19, 1999) (providing that individuals with a reasonable fear who would otherwise be subject to 8 U.S.C. $\$ 1231$ (a)(5)'s bar to "all relief under [the] Act," are still entitled to seek withholding of removal); Herrera-Molina v. Holder, 597 F.3d 128, 139 (2d Cir. 2010) (explaining that 
loggerheads with one another in their varying use of the words "may apply," even a simple analysis of the plain meaning and scope of the generic-relief regulation itself would conclusively rule out its application at least as to claims for withholding of removal.

These points, taken in conjunction with the fact that the three regulatory schemes (i.e., generic-relief, asylum-specific, and withholding-specific) were promulgated at the same time, reveal that it is simply wrong to apply the generic-relief regulation to either asylum or withholding claims. The generic-relief regulation and the asylum/withholding-specific regulations were first promulgated in $1997^{160}$ during the course of implementing the Illegal Immigration Reform and Immigrant Responsibility Act of 1996 ("IIRIRA"). ${ }^{161}$ As such, the drafters were clearly aware of the regulations specific to asylum and withholding of removal when crafting the genericrelief regulation and should be presumed to have intentionally used the disparate wording in the various regulatory schemes. ${ }^{162}$ In reading the

alien subject to reinstatement of removal under 8 U.S.C. $\S 1231$ (a)(5) is still eligible for withholding of removal).

160. See Inspection and Expedited Removal of Aliens; Detention and Removal of Aliens; Conduct of Removal Proceedings; Asylum Procedures, 62 Fed. Reg. 10312-01 (March 6, 1997).

161. Pub. L. No. 104-208 (1997). While there is no case that contains the generic-relief language of 8 C.F.R. \$ 1240.8 (d) earlier than IIRIRA, the pre-IIRIRA asylum regulations did contain similar "may apply" language in the context of the particularly serious crime bar, firm resettlement bar, and danger to security bar. See $\$ 208.14$ (c)(2) (1994) (first promulgated in 1990, 55 Fed. Reg. 30674-01). However, that asylum regulation made no reference at all to the persecutor bar. It provided that:

"If the evidence indicates that one or more of the grounds for denial of asylum enumerated in paragraph (c) of this section may apply, the applicant shall have the burden of proving by a preponderance of the evidence that such grounds do not apply.

(c) Mandatory denials. An application for asylum shall be denied if:

(1) The alien, having been convicted by a final judgment of a particularly serious crime in the United States, constitutes a danger to the community;

(2) The applicant has been firmly resettled within the meaning of $\$ 208.15$; or

(3) There are reasonable grounds for regarding the alien as a danger to the security of the United States."

162. See Matter of Villarreal-Zuniga, 23 I. \& N. Dec. 886, 889 (B.I.A. 2006) ("We construe the language of ... regulation[s] according to the same principles of interpretation applied in determining the meaning of a statutory provision.") (citing Matter of Masri, 22 I. \& N. Dec. 1145, 1148 (B.I.A. 1999)); Nat'l Ass'n of Home Builders v. Defenders of Wildlife, 551 U.S. 644, 668-69 (2007) (invoking the canon against surplusage in interpretation of regulations); INS v. Cardoza-Fonseca, 480 U.S. 421, 432 (1987) (using the canon of statutory construction that "[w]here ... particular language" is used in one section "but omit[ted] ... in another section of the same Act, it is generally presumed" to be "intentional[] and purpose[ful] in the disparate inclusion or exclusion.") (quoting Russello v. United States, 464 U.S. 16, 23 (1983)); Matter of Castro-Tum, 27 I. \& N. Dec. 271, 287 (B.I.A. 2018) ("I must adopt an interpretation that gives each regulation independent meaning, not one that renders ... [a] regulation unnecessary.") (citing Advocate Health Care Network v. Stapleton, 137 S. Ct. 1652, 1659 (2017) ("Our practice . . is to 'give effect, if possible, to every clause and word of a statute."') (quoting Williams v. Taylor, 529 U.S. 362, 404 (2000))); Yates v. United States, 135 S. Ct. 1074, 1085 (2015) (plurality opinion) ("We resist a reading of [the relevant statutory provision] that would render superfluous an entire provision passed in proximity as part of the same Act."); see also Black \& Decker Corp. v. Comm'r of Internal Revenue, 986 F.2d 60, 65 (4th Cir. 1993) ("Regulations, like statutes, are interpreted according to canons of construction. Chief among these canons is the mandate that "constructions which render regulatory provisions superfluous are to be avoided.'”) (quoting Hart v. McLucas, 535 F.2d 516, 519 (9th Cir. 1976)); Cont'l Cas. Co.v. United States, 314 U.S. 527, 533 (1942) ("Generally speaking a 'legislative affirmative description' 
regulations as a whole, it follows that the generic-relief regulation was only intended to apply to applications for relief that do not otherwise have a more specific regulatory regime. Because imposing the generic-relief regulation (which does use the words "may apply") onto the asylum/withholding-specific regulations (which do not use the words "may apply") would render superfluous the precise language selected in the more specific asylum/withholding regulations, the generic-relief regulation must not be applied to such claims. ${ }^{163}$ Rather, in order to give full effect to the asylum/ withholding-specific regulations, the generic-relief regulation must be cabined to only those forms of relief which do not have their own set of specific regulations. ${ }^{164}$ To do otherwise is to render a nullity the precise language utilized in the asylum/withholding-specific regulations. ${ }^{165}$

Despite the clear differences between the regulations specific to asylum/ withholding and the generic-relief regulation, the Board has yet to recognize any distinction between the divergent regulatory schemes. Instead, the Board appears to have reflexively defaulted to the generic-relief regulation to guide its analysis of claims for asylum and withholding of removal. ${ }^{166}$ It is not clear whether the Board has ever been called upon to decide the matter in the context of the persecutor bar; it seems to have simply assumed the generic-relief regulation's applicability. ${ }^{167}$ In reality, this should be regarded as an open question. As discussed in the next section, several courts have cast serious doubt upon whether use of the "may apply" language of 1240.8(d) in the persecutor bar context is consistent with the withholding and asylum statutes, which require respectively that the adjudicator decide or determine that a person assisted or otherwise participated in persecution. ${ }^{168}$

implies denial of the nondescribed powers."); Botany Worsted Mills v. United States, 278 U.S. 282, 289 (1929) ("When a statute limits a thing to be done in a particular mode, it includes the negative of any other mode.").

163. See infra Section IV.B.

164. See id.

165. Seeid.

166. See e.g., In re R-S-H-, 23 I. \& N. Dec. 629 (B.I.A. 2003); Matter of M-B-C-, 27 I. \& N. Dec. 31 , 38 (B.I.A. 2017).

167. See Matter of $M-B-C-, 27$ I. \& N. Dec. at 38. The only published Board decision which cites to both 8 C.F.R. $\S 1240.8$ (d) (i.e., the generic-relief regulation) and 8 C.F.R. $\$ 208.13$ (b)(2) (i.e., the asylum-specific regulation) is In re $R$-S-H- (utilizing the burden-shifting regulation in the context of the danger to security bar). The Board there simply assumed 8 C.F.R. $\S 1240.8$ (d) applied and did not otherwise apply the relevant portion of 8 C.F.R. $\$ 208.13($ b)(2).

168. The INA bars withholding of removal and asylum for those who "the Attorney General decide[s]" or "determines" have "assisted, or otherwise participated in the persecution of an individual" because of a protected characteristic. 8 U. S. C. $\$ \S 1231(\mathrm{~b})(3)(\mathrm{B})(\mathrm{i}) ; 1158(\mathrm{~b})(2)(\mathrm{A})(\mathrm{i})$ (emphasis added); see also Pastora v. Holder, 737 F.3d 902, 906 n. 5 (4th Cir. 2013) (noting that 8 C.F.R. $\$ 1240.8$ (d)'s language "may apply" could well be "in tension with the language of the statute" and that the Sixth, Second, and Seventh Circuits appear "to have read the word "may' out of the regulation"); Diaz-Zanatta v. Holder, 558 F.3d 450, 455 (6th Cir. 2009) (holding that "the record must reveal that the [applicant] actually assisted or otherwise participated in the persecution of another"); Gao v. U.S. Att'y Gen., 500 F.3d 93, 100 (2d Cir. 2007) (finding the evidence in that case insufficient "to trigger the persecutor bar without evidence indicating that Gao actually assisted in an identified act of persecution"); Singh v. Gonzales, 417 F.3d 736, 740 (7th Cir. 2005) ("for the statutory bars contained in ... [the withholding and asylum statutes] to apply, the record must reveal that the alien actually assisted or otherwise participated in the persecution"); Budiono v. Lynch, 837 F.3d 1042, 1048 (9th Cir. 2016) (explaining that in Kumar v. Holder, 


\section{B. Decisions Casting Doubt on the Use of the Generic-Relief Regulation in the Persecutor Bar Context}

In contrast to the approach espoused by the Board in $M-B-C-$, the Second, Sixth, Seventh, and Ninth Circuits have explicitly rejected arguments that evidence of possible assistance in persecution is sufficient to trigger the bar, ${ }^{169}$ and the Fourth Circuit has openly questioned such arguments. ${ }^{170}$ In each of these cases, the Courts anchored their analysis to the unambiguous text of the relevant statutes.

In Diaz-Zanatta, a Sixth Circuit case, the government argued that evidence that: (1) "Diaz-Zanatta collected intelligence information and provided that information to her supervisors" in the Peruvian military, and (2) that "elements of the Peruvian military ... engaged in persecution," was sufficient to indicate that she may have assisted or participated in persecution such that the bar applied. ${ }^{171}$ However, the Court explicitly rejected the government's argument explaining that absent "evidence linking Diaz-Zanatta's information gathering to persecution," it could not find "that she "actually assisted or otherwise participated in ... persecution." "'172 The Court reasoned that "mere employment in the Peruvian military intelligence community does not permit the conclusion that ... she assisted or otherwise participated in any persecution." "173 The Court stated that "under [the IJ's] reasoning, if [the applicant] had collected intelligence solely on teachers in Peru, and no one but lumberjacks had been persecuted by the military, [the applicant] would nonetheless have assisted or participated in persecution., ${ }^{174}$ Rejecting this flawed analysis, the Court held that "the record [must] demonstrate[] some actual connection between ... [the applicant's] actions and the persecutions in which she is alleged to have assisted" and "the IJ must determine from the evidence in the record that ... [the applicant] knew that the information she supplied ... was being used to persecute." 175

Likewise, the Second Circuit rebuffed an almost identical version of the argument advanced by the government in Diaz-Zanatta, cautioning against "permitting generalities or attenuated links to constitute 'assistance." 176 The Court in Gao likewise held that "the record ... [there did] not disclose any actual act of persecution in which Gao allegedly assisted." 177 As such, the

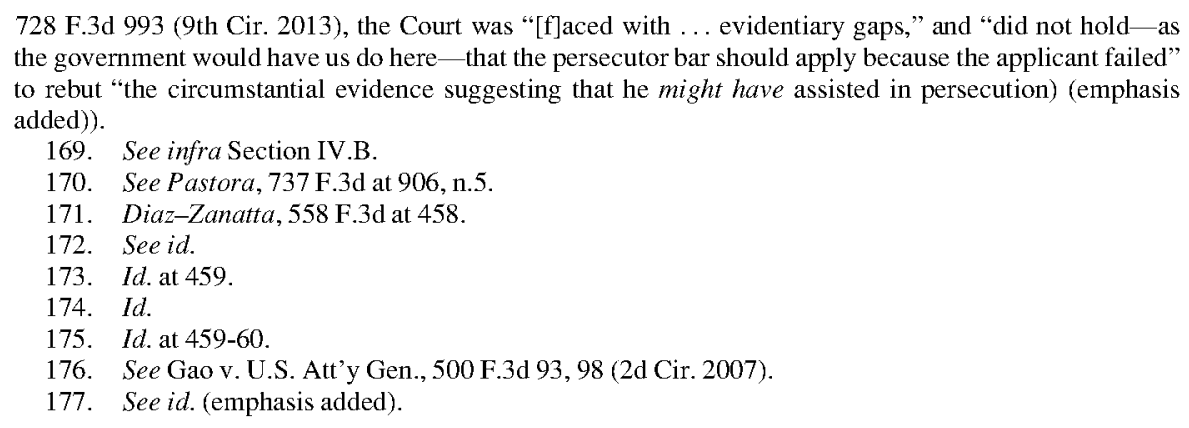


Court rejected the government's argument that evidence that Gao was an administrator within the Culture Management Bureau (an agency providing information to the Chinese government that "could" lead to the arrest of individuals for political reasons) was sufficient to find that the persecutor bar may apply. ${ }^{178}$ The Court states that "the mere fact that Gao may be associated with an enterprise that engages in persecution is insufficient by itself to trigger the effects of the persecutor bar." ${ }^{179}$ Rather, the Court held that "[b]efore we can determine whether Gao's conduct 'contributed directly' to persecution..., the record must first reveal an identifiable act of persecution," 180 in which "Gao actually assisted." 181 Thus the court concludes that "the act of issuing a report that could potentially be used to arrest an individual is insufficient to constitute a "direct link' to persecution." ${ }^{182}$ Similar analysis can be found in the Seventh Circuit, in Singh v. Gonzales, and the Ninth Circuit in Budiono v. Lynch. ${ }^{183}$

In construing these four decisions, the Fourth Circuit in Pastorav. Holder, ${ }^{184}$ suggested that the generic-relief regulation's "may apply" language could well be "in tension with the language of the statute." 185 The Court in Pastora thus understood the decisions in Diaz-Zanatta, Gao, Singh, and Budiono "to have read the word "may' out of the regulation." 186 Indeed, the holdings of those decisions, like the asylum and withholding statutes themselves, are utterly irreconcilable with Matter of $M-B-C$-'s use of the generic-relief regulation to allow for application of the persecutor bar on a mere possibility that a refugee assisted or participated in persecution. ${ }^{187}$ At a minimum, the foregoing decisions must be read to reject any decontextualized understanding of the generic-relief regulation such that nullifies the statutes' mandate that the adjudicator decide/determine that the applicant assisted in persecution. ${ }^{188}$ While one solution may be-as the Fourth Circuit suggested - to read "may" out of the regulation, there are problems with this approach given the extensive deference afforded to an agency's interpretation its own regulation. ${ }^{189}$ A more straightforward approach — and the one I adopt

\footnotetext{
178. Id. at $95-100$ (emphasis added).

179. Id. at 99 .

180. Id. at 100-101 (emphasis added).

181. Id.

182. Id. at 102 (emphasis added).

183. Singh v. Gonzales, 417 F.3d 736, 740 (7th Cir. 2005) ("[T] he record must reveal that the alien actually assisted or otherwise participated in the persecution."); Budiono v. Lynch, 837 F.3d 1042, 1048 (9th Cir. 2016) (explaining an earlier decisions that "did not hold-as the government would have us do here-that the persecutor bar should apply because the applicant failed" to rebut "the circumstantial evidence suggesting that he might have assisted in persecution) (emphasis added).

184. 737 F.3d 902, 906, n.5 (4th Cir. 2013).

185. Id.

186. Id.

187. Matter of M-B-C-, 27 I. \& N. Dec. 31,38 (B.I.A. 2017).

188. See 8 U.S.C. $\$ \S 1231$ (b)(3)(B)(i); 1158(b)(1)(B)(i).

189. Auer v. Robbins, 519 U.S. 452, 457, 461 (1997); Chevron, U.S.A. v. Nat'l Resources Defense Council, 467 U.S. 873 (1984); Bowles v. Seminole Rock \& Sand Co., 325 U.S. 410, 413-14 (1945).
} 
in this article-is to reject use of the generic-relief regulation altogether in the persecutor bar context.

Indeed, any interpretation of the generic-relief regulation that allows a person facing a clear probability of persecution in her home country to be returned to that country on the mere possibility that she was involved in persecution cannot be correct. ${ }^{190}$ Because this problem was brought to the attention of the Board in Matter of Negusie, and it declined to interpret the regulation in a manner that would dispositively eliminate the risk of the "laxprocedure approach," I maintain that the generic-relief regulation must not be applied to the persecutor bar at all. This is true both because of the grave consequences that result from application of the bar and because it is the most harmonious interpretation of the statute, the asylum/withholding-specific regulations, and analogous regulatory frameworks adopted by the Board. ${ }^{191}$

\section{Guiding Principles for Crafting Adequate Procedural Safeguards}

Because the current use of the generic-relief regulation is not a sound foundation on which to build a procedural framework for applying the persecutor bar, it is necessary to look to another source to anchor the analysis. Yet, before outlining the contours of those proposed procedural safeguards, it is important to discuss the normative methodology employed here in approaching the question. There are three principles that should serve to guide the analysis.

First, the proposed procedural safeguards must be crafted in a manner that recognizes the severe consequences that adhere in application of the bar in the worst-case-scenario. The persecutor bar renders one ineligible not just for withholding of removal and asylum, but also bars relief in a number of other contexts. ${ }^{192}$ Because the BIA and courts interpret and construe the virtually identical persecutor bar language the same, ${ }^{193}$ it is crucial to analyze application of the bar and the necessary procedural safeguards in the specific context

190. See infra Section IV.B.

191. See infra Section II.C.; Matter of Villarreal-Zuniga, 23 I. \& N. Dec. 886,889 (B.I.A. 2006) ("In ascertaining the plain meaning of a statutory provision, we read the language in harmony with the wording and design of the statute as a whole .... [A] statute or regulation should be construed so that effect is given to all its provisions, so that no part of it will be inoperative or superfluous, void or insignificant.") (citing Matter of Nolasco, 22 I. \& N. Dec. 632, 636 (B.I.A. 1999); Matter of Smriko, 23 I. \& N. Dec. 836, 838 (B.I.A. 2005); Matter of Masri, 22 I. \& N. Dec. 1145, 1148 (B.I.A. 1999)); see also Matter of Y-L-, 24 I. \& N. Dec. at 155, 158 (explaining the necessary procedural safeguards in the frivolous asylum bar context) (emphasis added); Matter of A-G-G-, 25 I. \& N. Dec. 486, 501-03 (B.I.A. 2011) (setting forth the BIA's "framework for making firm resettlement" bar determinations).

192. See supra note 47.

193. A single definition of "persecution" applies both in the context of eligibility for withholding of removal (the core duty of non-refoulment) and in defining the persecutor bar to withholding, asylum, and others forms of relief. See Matter of Rodriguez-Majano, 19 I. \& N. Dec. 811, 816 (B.I.A. 1988) ("As the concept of what constitutes persecution [in the context of relief] expands, the group which is barred from seeking haven in this country [due to the persecutor bar] also expands..."), overruled on other grounds by Negusie v. Holder, 555 U.S. 1159, 1167 (2009). 
where the consequences are most serious. ${ }^{194}$ In the withholding context, the persecutor bar authorizes the return of a person facing a clear probability of persecution in her home country, ${ }^{195}$ and thus the procedural analysis must be weighed and considered within that paradigmatic context. ${ }^{196}$ The approach I take here is in marked contrast to that the Board has taken in past decisions, which seem to instead elaborate on the persecutor bar in the context of applications for relief - such as NACARA - where the stakes are the lowest. ${ }^{197}$

Second, those safeguards must be developed consistently with the language and overall purpose of the Refugee Act. The persecutor bar's sequential application — and the standards for applying the bar-must be anchored in the withholding of removal and asylum provisions of the INA in a manner that is consistent with our obligations under the Refugee Convention and Protocol. ${ }^{198}$ Any procedural rule as applied to the persecutor bar that nullifies the statutes' requirement to determine or decide that an applicant participated in persecution ${ }^{199}$ is ultra vires. ${ }^{200}$ As such, any use or interpretation of a regulation that allows for application of the bar on anything less than a definitive determination that an applicant actually "assisted, or otherwise participated in" persecution is simply incompatible with the language and purposes of the statute. $^{201}$

Third, the safeguards should be responsive to analogous regulatory schemes created by the Board in the context of similar bars. The only acceptable procedural framework for applying the persecutor bar is one that forms a "symmetrical and coherent regulatory scheme"202 that aligns with the

194. See Gao v. U.S. Att'y. Gen., 500 F.3d 93, 98 (2d Cir. 2007) ("In evaluating a persecutor bar claim, it must be remembered that this provision authorizes the deportation of individuals who have established that they would likely be persecuted ... [so] courts must be cautious before permitting generalities or attenuated links to constitute 'assistance."').

195. See I.N.S. v. Cardoza-Fonseca, 480 U.S. 421, 440 (1987).

196. See Gao, 500 F.3d at 98.

197. See supra Section I.B.

198. Negusie, 555 U.S. at 1168; UN HIGH COMM'R FOR REFugeES (UNHCR), Guidelines on International Protection, II 2 (2003) (noting "the possible serious consequences of exclusion"); UNHCR, Background Note on the Application of the Exclusion Clauses, III 3-5 (2003) (explaining that exclusion "must be view in the context of the overriding humanitarian objective of the 1951 Convention"); Ezokola, [2013] 2 S.C.R. 678 at 693 (Can.) ("The preamble to the Refugee Convention highlights the international community's ... commitment 'to assure refugees the widest possible exercise of ... fundamental rights and freedoms.' Our approach to art. $1 \mathrm{~F}$ (a) must reflect this 'overarching and clear human rights object and purpose." ) (internal citations omitted).

199. See 8 U.S.C. $\$ \S 1158($ b)(2)(A)(i); 1231(b)(3). Those statutes provide that individuals for whom "the Attorney General decide[s]" or "determines" have "ordered, incited, assisted, or otherwise participated in ... persecution" are ineligible for asylum and withholding of removal. See infra Section IV.B.

200. Auer v. Robbins, 519 U.S. 452, 457, 461 (1997) (noting that an administrative approach can only be sustained if it is "based on a permissible construction of the statute" and that an interpretation of a regulation cannot control if it is "plainly erroneous or inconsistent with the regulation") (citing Chevron, U.S.A. v. Nat'l Resources Defense Council, 467 U.S. 873 (1984); Bowles v. Seminole Rock \& Sand Co., 325 U.S. 410, 413-14 (1945)); Mohasco Corp. v. Silver, 447 U.S. 807, 825 (1980) ("As we have held on prior occasions, [an agency'] 'interpretation' of the statute cannot supersede the language chosen by Congress.").

201. See I.N.S. v. Cardoza-Fonseca, 480 U.S. 421, 440 (1987).

202. See FDA v. Brown \& Williamson Tobacco Corp., 529 U.S. 120, 132-33 (2000); Matter of C-TL-, 25 I. \& N. Dec. 341, 347-48 (BIA 2010) (citing FDA v. Brown \& Williamson for proposition that 
Board's explanation of other asylum bars having less serious consequences. ${ }^{203}$ Specifically, the Board has developed relatively robust procedural safeguards in the context of the firm resettlement bar and frivolous asylum bar that should serve as a baseline for the necessary procedural safeguards in the more serious persecutor bar context. ${ }^{204}$

In the following two sections, I employ the foregoing theoretical framework to craft protective procedural safeguards for applying the persecutor bar (and its duress defense). These proposed procedural safeguards are broken down into two components. The first component, enumerated in section three, discusses the necessary substantive elements of "assistance or participation" in persecution, which were largely adopted by the Board in Matter of Negusie. ${ }^{205}$ In sum, before an adjudicator can determine that the bar applies, she must make factual findings based upon a preponderance of the evidence in relation to each of the four elements that make up "assistance or participation" in persecution. ${ }^{206}$ The second component, detailed in the last section, advocates for procedural safeguards that will foreclose further use of the laxprocedure approach that still threatens genuine refugees. ${ }^{207}$ Those proposed procedures require that an applicant be given notice and opportunity to show that DHS has not met its initial preponderance burden. If the applicant cannot rebut DHS's evidence, it may be determined that the bar is triggered, and the burden then shifts to the applicant to show by a preponderance of the evidence that the applicant's involvement in persecution was the result of duress. Only after it is determined that the applicant has failed to meet that burden, can the bar actually be applied.

\section{The Four Substantive Preliminary Findings Regarding Whether The Applicant Assisted Or Participated In Persecution}

Without an identified act of persecution there is no occasion to reach questions of assistance or participation. That initial set of findings related to

where key language Congress used to define persecution in the withholding and asylum statutes presumably has the same meaning, adopting different standards for the two forms of relief would be "unharmonious and asymmetrical.").

203. See e.g., Matter of Y-L-, 24 I. \& N. Dec. at 157, 158 (holding that because a "frivolousness finding ... forever bars an alien from any benefit under the Act ..., the preponderance of the evidence must support an Immigration Judge's finding") (emphasis added); Matter of A-G-G-, 25 I. \& N. Dec. 486, 50103 (B.I.A. 2011) (setting forth a similar four-step analysis for the BIA's "framework for making firm resettlement" bar determinations, in which DHS bears the initial burden of proof). Below, I analyze these analogous bars and the procedural safeguards adopted there to create what should serve as a benchmark in the persecutor bar context.

204. See infra Section IV.A for a more fulsome discussion of these analogous safeguards.

205. See infra Section III. Although, as noted above, AG Barr is reviewing Matter of Negusie. See supra note 38 .

206. Those four elements are: (1) an identifiable act sufficiently severe to constitute persecution; (2) a nexus between the identified act of persecution and a protected characteristic of the victim; (3) a finding that the applicant's conduct was connected to that identified act of persecution and involved more than mere membership in a group that engages in persecution generally; and (4) a finding that the applicant had the requisite scienter (i.e., "prior or contemporaneous knowledge"). See infra Section III.

207. See infra Section IV. 
specific acts of persecution is a necessary "procedural safeguard" in the overall application of the persecutor bar because it ensures that a would-be refugee is not forced $a b$ initio to prove in the abstract that she did not assist in persecution. ${ }^{208}$ In contrast to the cases discussed in Section I.B above, ${ }^{209}$ a fair application of this rule will put the refugee on notice as to the specific conduct which is being impugned before she is required to assert arguments absolving her of culpability. Moreover, requiring these specific findings should not be onerous for the adjudicator since before reaching this step of the analysis, the applicant must have already been found to otherwise meet the definition of a refugee. ${ }^{210}$

As stated above, the INA bars withholding of removal and asylum for those who "the Attorney General decide[s]" or "determines" have "assisted, or otherwise participated in the persecution of an individual because of the individual's race, religion, nationality, membership in a particular social group, or political opinion." ${ }^{211}$ In determining whether the persecutor bar applies, an adjudicator must specifically find: (1) an identifiable act sufficiently severe to constitute persecution; (2) that the identified act of persecution was inflicted on account of a protected characteristic of the victim; (3) that the applicant's conduct was connected to that identified act of persecution and involved more than mere membership in a group that engages in persecution generally; and (4) that the applicant had the requisite scienter (i.e., "prior or contemporaneous knowledge"). ${ }^{212}$ Each of these elements is discussed in greater detail below. ${ }^{213}$

\section{A. An Act Sufficiently Severe To Constitute Persecution}

A determination that persecution occurred requires factual findings related to the severity of harm. ${ }^{214}$ The term persecution has the same meaning in the context of seeking relief as it does in the context of the persecutor bar. ${ }^{215}$

\footnotetext{
208. See e.g., Matter of Y-L-, 24 I. \& N. Dec. 151, 155 (B.I.A. 2007) (discussing safeguards in the frivolous asylum bar context).

209. See supra Section I.B.

210. Matter of Negusie, 27 I. \& N. Dec. 347, 366 (B.I.A. 2018) ("The adjudicator should first determine whether the applicant is otherwise eligible for asylum or withholding of removal" before reaching the question of duress); $i d$. at 367 ("[I]ssues raised in these cases involve similar complexities of factfinding against a common legal standard ... . Recognition of such a [duress] defense, therefore, would not constitute a departure from the types of questions commonly addressed by the Board and Immigration Courts. Nor would it impose burdens of fact-finding that are not already encountered in addressing such questions"). As this article goes to print, Matter of Negusie is still under review. While the AG may overrule aspects of the decision, Matter of Negusie's reasoning will remain instructive regardless of the AG's decision. As such, I have continued to cite the relevant portions of Matter of Negusie in this section.

211. 8 U.S.C. $\$ \S 1231($ b)(3)(B)(i); $1158($ b)(2)(A)(i) (emphasis added).

212. Matter of Negusie, 27 I. \& N. Dec. at 366.

213. See id:; infra Section III.A. through III.D.

214. Matter of Negusie, 27 I. \& N. Dec. at 366; Lim v. INS, 224 F.3d 929, 936 (9th Cir. 2000); Butt v. Keisler, 506 F.3d 86, 90 (1st Cir. 2007).

215. Matter of Negusie, 27 I. \& N. Dec. at 366 ("[W]e interpret the term "persecution" in the persecutor bar as carrying the same meaning as it does in the context of determining an alien's eligibility for asylum or withholding of removal'); Matter of Fuentes, 19 I. \& N. Dec. 658, 663 (B.I.A. 1988) (emphasis added); see also Matter of Rodriguez-Majano, 19 I. \& N. Dec. 811, 816 (B.I.A. 1988) (noting that "the
} 
While the term "persecution" is not defined in the INA, the significant body of law developed around eligibility for relief is instructive for understanding the level of harm required in the persecutor bar context. ${ }^{216}$

Numerous courts have explained that a "single, isolated incident, or abuse resulting in minimal injury, does not usually rise to the level of persecutor harm.,"217 Rather, the term persecution has been described as a concept limited to harms that reach a "fairly high threshold of seriousness." 18 Because the statute-which defines both eligibility for relief and the bar to reliefuses the same term, persecution, there can be no principled reason to interpret that term differently in the persecutor bar context than in the context where one is seeking eligibility for asylum or withholding of removal. ${ }^{219}$ While the Board in Matter of Negusie did not belabor the point, it did begin its analysis of its framework for applying the bar with a recognition that "we interpret the term 'persecution' in the persecutor bar as carrying the same meaning as it does in the context of determining an alien's eligibility for asylum or withholding of removal.,"220

Therefore, absent a showing of sufficiently severe harm, there is no need to conduct further analysis related to whether an applicant participated in

concept of what constitutes persecution" in the context of relief is coextensive with the concept of what constitutes persecution in the context of the persecutor bar), overruled on other grounds by Negusie $v$. Holder, 555 U.S. 511, 522-23 (2009).

216. Matter of Negusie, 27 I. \& N. Dec. at 366.

217. See Deborah E. Anker, LAw OF Asylum IN The U.S. \$ 4:13 (2018 ed.) (citing Thapaliya v. Holder, 750 F.3d 56, 59 (1st Cir. 2014) (holding that an isolated beating and threats did not constitute persecution, noting that "isolated beatings have been commonly rejected as grounds for persecution"); Jian Qiu Liu v. Holder, 632 F.3d 820, 822 (2d Cir. 2011) (finding the petitioner's physical altercation with family planning officials to be insufficient for a finding of past persecution where "he suffered only minor bruising ... which required no formal medical attention and had no lasting physical effect"); Cabas $v$. Holder, 695 F.3d 169, 174 (1st Cir. 2012) (receipt of several threats and one incident where petitioner was "kidnapped, beaten, and left unconscious in a remote location" did not compel conclusion that petitioner suffered persecution); Hussain v. Holder, 576 F.3d 54, 57 (1st Cir. 2009) (finding that to constitute persecution, a person's experience must rise above "unpleasantness, harassment, and even basic suffering") (citation and internal quotation marks omitted); Touch v. Holder, 568 F.3d 32, 39 (1st Cir. 2009) (noting that, "although the government unquestionably mistreated [applicant] during the protests-beating him and forcing him to drink wastewater - [applicant] did not suffer serious or permanent injuries"); Ritonga v. Holder, 633 F.3d 971, 976 (10th Cir. 2011) ("Ritonga suffered minor injuries only once .... [W] cannot say this constituted persecution.")); Bracic v. Holder, 603 F.3d 1027, 1035 (8th Cir. 2010) ("[O]ne episode of physical mistreatment does not necessarily require the Court to find that the respondent suffered past persecution.") (citations and internal quotation marks omitted)); Nzeve v. Holder, 582 F.3d 678, 684 (7th Cir. 2009) (finding that single assault where petitioner was beaten with batons, kicked, hit with a gun, and which resulted in blisters and bruising did not compel a finding of past persecution); Mekhtiev v. Holder, 559 F.3d 725, 730 (7th Cir. 2009) (denying petition for review where petitioner was "detained overnight and beaten one time," but "[h]is resultant injuries d[id] not appear to have been severe," "requir[ing] only stitches and bed rest"); Liu v. Ashcroft, 380 F.3d 307, 313-14 (7th Cir. 2004) (concluding that brief detention, hair-pulling, verbal taunting and interrogation, and search of home did not constitute persecution).

218. See Lim v. INS, 224 F.3d 929, 936 (9th Cir. 2000) ("We have defined persecution as an "extreme concept' that includes the "infliction of suffering or harm." (internal citations omitted); Butt $v$. Keisler, 506 F.3d 86, 90 (1st Cir. 2007). To be clear, I am not advocating for a higher-than-normal threshold for harm to constitute persecution in the persecutor bar context than in the relief context. Rather, the same term should be construed the same in both contexts.

219. See Matter of Rodriguez-Majano, 19 I. \& N. Dec. 811,816 (B.I.A. 1988), overruled on other grounds by Negusie, 555 U.S. at 522-23.

220. See Matter of Negusie, 27 I. \& N. Dec. 347, 366 (B.I.A. 2018). 
persecution. However, if there is evidence that sufficiently severe harm occurred, the analysis must then proceed to consider whether there is a nexus between the harm inflicted and a protected characteristic.

\section{B. On Account Of A Protected Characteristic Of The Victim}

Consistent with the statutory language of the persecutor bar itself, the act of harm identified above must have been inflicted because of a victim's protected characteristic. ${ }^{221}$ The Board has long recognized the importance of considering nexus in the persecutor bar context:

[I]f one were to find that a policeman or guerrilla was a victim of 'persecution' within the scope of the Act based solely on the fact of an attack by one against the other, then it would follow that the attacker had participated in an act of 'persecution' that would forever bar him or her from relief ..... Such a 'broad' interpretation of the concept of persecution on account of [a protected characteristic] would have the actual effect of greatly narrowing the group of persons eligible for asylum and withholding. Virtually all participants on either side of an armed struggle could be characterized as 'persecutors' and would thereby be ineligible for asylum or withholding of deportation. The concept of 'persecution' has not been so broadly defined. ${ }^{222}$

The Board further elaborated that harm or injury inflicted as a natural consequence of civil strife is not persecution, as there is no nexus to a protected

221. Matter of Negusie, 27 I. \& N. Dec. at 349, 369; 8 U.S.C. $\$ 1231$ (b)(3)(B)(i) (requiring the Attorney General to decide the applicant assisted or participated in "the persecution of an individual because of race, religion, nationality, membership in a particular social group, or political opinion"); see also 8 U.S.C. $\$ 1158(b)(1)(B)(i)$ (explaining that an applicant is not eligible for asylum if she or she "assisted or ... participated in the persecution ... on account of" one of the protected characteristics) (emphasis added); 8 U.S.C. $\$ 1101(\mathrm{a})(42)($ A) (same); 8 C.F.R. $\$ 1208.13(\mathrm{c})(2)(\mathrm{i})(\mathrm{E})$ (same); Negusie, 555 U.S. at 515 (noting that "[i]t was undisputed that the prisoners [respondent] guarded were being persecuted on account of a protected ground"); Budiono v. Lynch, 837 F.3d 1042, 1048 (9th Cir. 2016) (explaining in the persecutor bar context that "[t]he persecution must ... be based on a protected ground, which would qualify the persecuted individual for refugee status in the United States."); Miranda Alvarado v. Gonzales, 449 F.3d 915, 925, 930 (9th Cir. 2006) (same); Meng v. Holder, 770 F.3d 1071, 1074 ( $2 \mathrm{~d}$ Cir. 2014) ("a nexus must be shown between the persecution and the victim's race, religion, nationality, membership in a particular social group, or political opinion") (internal citations and quotation marks omitted); Diaz-Zanatta v. Holder, 578 F.3d 450 (6th Cir. 2009) (reversing denial of asylum where, inter alia, there was no proof of a nexus); Balachova v. Mukasey, 547 F.3d 374, 384-87 (2d Cir. 2008) (holding that the bar did not apply regardless of the level of assistance because there "was no showing of a "nexus"' to a protected ground); Matter of Fuentes, 19 I. \& N. Dec. 658, 663 (B.I.A. 1988) (noting that there must be a nexus to determine one has engaged in persecution); Matter of Rodriguez-Majano, 19 I. \& N. Dec. $811,815-16$ (B.I.A. 1988) (explaining that harm is not persecution unless it is "directed at someone on account of one of the five categories enumerated in section [1101(a)(42)(A)]"), overruled on other grounds by Negusie, 555 U.S. at 522-23); Matter of J.M. Alvarado, 27 I. \& N. Dec. 27, 29-30 (B.I. A. 2017) (positively citing Rodriguez-Majano for the proposition that when "analyzing a claim of persecution ..., one must examine the motivation" of "those who committed the underlying persecutory acts" to determine if such acts were committed on account of a protected characteristic).

222. Matter of Fuentes, 19 I. \& N. Dec. 658, 663 (B.I.A. 1988) (emphasis added). 
characteristic. ${ }^{223}$ Similarly, in Matter of Rodriguez-Majano the Board states that "[i]n analyzing a claim of persecution in the context of civil war, one must examine the motivation of the group threatening harm."224

This is not to say, necessarily, that there is a requirement for the applicantalleged to have assisted in persecution-to share a persecutory motive with those engaged in direct persecution to apply the bar. The Board recently considered this specific question and concluded that an applicant's "personal motivation [on the question of nexus] is not relevant" to the persecutor bar analysis. ${ }^{225}$ Whether courts will defer to that interpretation remains to be seen. ${ }^{226}$ Regardless of the answer to that specific question, if the record fails to establish a nexus between the sufficiently severe harm identified in step one above and a protected characteristic, then an applicant may not be found to have assisted or participated in persecution because there is no underlying act of persecution. ${ }^{227}$ Here too, the Board in Matter of Negusie briefly reaffirmed this point by stating that "we interpret the term 'persecution' in the persecutor bar as carrying the same meaning as it does in the context of determining an alien's eligibility for asylum or withholding of removal," 228 thus incorporating the ordinary nexus analysis utilized when applying for relief. ${ }^{229}$

\section{A Connection Between The Applicant's Conduct And The Identified Act Of Persecution}

Once it has been determined that an identifiable act of persecution has occurred, the analysis may then proceed to consider whether there is a sufficient connection between the applicant's "role, acts, or inaction" and the identified act of persecution. ${ }^{230}$ As such, an individual's responsibility or

223. Id.; Matter of Rodriguez-Majano, 19 I. \& N. Dec. $811,815-16$ (B.I.A. 1988) (finding that "activities directly related to a civil war" are not persecution because "harm which may result incidentally from behavior directed at another goal ... [i.e.] the defense of [a] government against an opponent" is not done with the "intent [to] ... overcome a [protected] belief or characteristic ...."), overruled on other grounds by Negusie, 555 U.S. at 522-23.

224. See Matter of Rodriguez-Majano, 19 I. \& N. Dec. at 815-16 (where the evidence showed that "respondent engaged only in military activities of the type normal in such conflicts . .," such activity "cannot be said to constitute persecution")

225. Matter of Alvarado, 27 I. \& N. Dec. 27, 29 (B.I.A. 2017).

226. Cf. Hernandez v. Reno, 258 F.3d 806, 814-815 (8th Cir. 2001) (reversing the BIA where it failed to consider respondent's "uncontroverted testimony that . . . he shared no persecutory motive" with the persecutor he was allegedly assisting).

227. Gao v. U.S. Atty' Gen., 500 F.3d 93, 100 (2d Cir. 2007) ("Before we can determine whether [the applicant's] conduct contributed directly to persecution ..., the record must first reveal an identifiable act of persecution in which [the applicant] allegedly assisted.").

228. See Matter of Negusie, 27 I. \& N. Dec. 347, 366 (B.I.A. 2018).

229. See id. at 349 (noting that the prisoners who Mr. Negusie guarded were "tortured ... on account of a protected ground.").

230. See Matter of Negusie, 27 I. \& N. Dec. at 367; Gao, 500 F.3d 93 at 100; Hernandez, 258 F.3d at 813 (a "court ... should engage in a particularized evaluation in order to determine whether an individual's behavior was culpable to such a degree that he could be fairly deemed to have assisted or participated in persecution.') (emphasis added); 8 U.S.C. $\$ \S 1231(\mathrm{~b})(3)(\mathrm{B})(\mathrm{i}), 1158(\mathrm{~b})(1)(\mathrm{B})(\mathrm{i}), 1101(\mathrm{a})(42)(\mathrm{A})$; 8 C.F.R. $\S 1208.13(\mathrm{c})(2)(\mathrm{i})(\mathrm{E})$. 
culpability must be assessed along a continuum of conduct from actions integral to the persecution of others to actions that are only tangential. ${ }^{231}$

There is substantial support for the principle that the applicant's "assistance" or "participation" must be purposeful and material to the persecutory act, and not tangential, indirect, or otherwise inconsequential. ${ }^{232}$ To constitute genuine assistance, the adjudicator must consider whether the applicant had "direct personal involvement" or played a "material," "integral" role that "furthered" the persecutory act; tangential, indirect, or inconsequential association will not be sufficient to trigger the bar. ${ }^{233}$

The facts and holdings in Singh v. Gonzales, Gao v. INS, and Higuit v. Gonzales, are instructive. ${ }^{234}$ In Singh, the Court found that mere membership in the Punjabi police during the period of persecution would not fall within the statutory prohibitions, but Singh's role in taking Sikhs into custody and transporting them to the police station, where he knew they would be subjected to physical abuse, constituted assistance in persecution. ${ }^{235}$ In making this determination, the Court emphasized the frequency of the conduct and Singh's awareness of the persecution. ${ }^{236}$ In Gao, the Court likewise concluded that by transporting captive women to locations where they were

231. See Miranda-Alvarado v. Gonzalez, 449 F.3d 915 (9th Cir. 2006); Weng v. Holder, 562 F.3d 510 (2d Cir. 2009); Gao v. INS, 434 F.3d 136, 142 (2d Cir. 2006) ("Where the conduct was active and had direct consequences for the victims, we concluded that it was 'assistance' in persecution. Where the conduct was tangential to the acts of oppression and passive in nature, however, we declined to hold that it amounted to such assistance."); Chen v. U.S. Att'y Gen., 513 F.3d 1255, 1259 (11th Cir. 2008) ("The standard ... is a particularized, fact-specific inquiry into whether the applicant's personal conduct was merely indirect, peripheral and inconsequential association or was active, direct, and integral to the underlying persecution.") A footnote in Fedorenko v. United States, 449 U.S. 490, 512 n.34, is cited frequently in this analysis of a continuum of culpable conduct. The Court put the matter this way:

[A]n individual who did no more than cut the hair of female inmates before they were executed cannot be found to have assisted in the persecution of civilians. On the other hand, there can be no question that a guard who was issued a uniform and armed with a rifle and a pistol, who was paid a stipend and was regularly allowed to leave the concentration camp to visit a nearby village, and who admitted to shooting at escaping inmates on orders from the commandant of the camp, fits within the statutory language about persons who assisted in the persecution of civilians.

232. See e.g., Kumar v. Holder, 728 F.3d 993, $998-99$ (9th Cir. 2013) (holding that the applicant's action must constitute "personal involvement and purposeful assistance" and that to determine "personal involvement," IJs should assess whether (1) the "involvement was active or passive" and (2) the applicant's acts were "material to the persecutory end."); Chen, 513 F.3d at 1259 (holding that the key inquiry is "whether the applicant's personal conduct was merely indirect, peripheral and inconsequential association or was active, direct and integral to the underlying persecution"); Gao, 500 F.3d at 99 ("Where the conduct was active and had direct consequences for the victims, we concluded that it was 'assistance in persecution.' Where the conduct was tangential to the acts of oppression and passive in nature, however, we declined to hold that it amounted to such assistance.") (internal quotations omitted); Miranda Alvarado v. Gonzales, 449 F.3d 915, 927-28 (9th Cir. 2006) (noting that the applicant's acts must be in "furtherance of" the persecution, not merely "peripheral"); Matter of Rodriguez-Majano, 19 I. \& N. Dec 811,815 (B.I.A. 1988) (concluding that an applicant is subject to the persecutor bar only if his or her "action or inaction furthers [the] persecution in some way.").

233. Matter of D-R-, 27 I. \& N. Dec. 105, 120 (B.I.A. 2017) (requiring consideration of whether the applicant had "direct personal involvement" and whether the applicant's "role was material or integral" to the harm, but eschewing the passive/active distinction).

234. Singh v. Gonzales, 417 F.3d 736 (7th Cir. 2005); Xie v. INS, 434 F.3d 136 (2d Cir. 2006);

Higuit v. Gonzales, 433 F.3d 417 (4th Cir. 2006).

235. See Singh, 417 U.S. at 740 .

236. Id. 
forced to undergo abortions, respondent played an active and direct role in the persecution. ${ }^{237}$ The Court pointed out that the respondent was a necessary link in the chain leading to persecution. ${ }^{238}$ Similarly, in Higuit, the Court found that an applicant who had served as an intelligence officer in the repressive Ferdinand Marcos regime for more than 10 years was barred from asylum because that "[respondent] was aware that his information-gathering and infiltration led to the torture, imprisonment, and death of Ipolitical opponents]."239

In contrast, it has long been held that group membership alone cannot constitute genuine assistance or participation in a persecutory act. ${ }^{240}$ Indeed, the BIA has held since 1988 that "mere membership in an organization, even one which engages in persecution, is not sufficient to bar one from relief" as a persecutor. ${ }^{241}$ Nearly every circuit to have considered the issue has agreed that membership alone is not sufficient to apply the bar. ${ }^{242}$ This conclusion is also in keeping with the consensus developed under international law interpretations. ${ }^{243}$ The war crimes tribunals, for example, distinguished between individual criminal liability and mere membership in an organization that engaged in war crimes. ${ }^{244}$ And, the UNHCR Guidelines explicitly state that

237. See Xie, 434 F.3d at 142 .

238. See id. at 143.

239. See Higuit, 433 F.3d at 417 (emphasis added).

240. See Matter of Rodriguez-Majano, 19 I. \& N. Dec. 811, 814 (B.I.A. 1988); see also Gao v. U.S. Atty'l Gen., 500 F.3d 93, 99 (2d Cir. 2007) (holding that "the mere fact that [Respondent] may be associated with an enterprise that engages in persecution is insufficient by itself to trigger the effects of the persecutor bar.").

241. Matter of Rodriguez-Majano, 19 I. \& N. Dec. at 814-15.

242. See Diaz-Zanatta v. Holder, 558 F.3d 450, 455 (6th Cir. 2009) (noting that "a distinction must be made between genuine assistance in persecution and inconsequential association with the persecutors"); Gao, 500 F.3d at 99 ("the mere fact that Gao may be associated with an enterprise that engages in persecution is insufficient by itself to trigger the effects of the persecutor bar"); Miranda Alvarado v. Gonzales, 449 F.3d 915, 929 (9th Cir. 2006) (noting that "mere acquiescence," membership in an organization, or simply being a bystander to persecutory conduct are insufficient to trigger the persecutor bar); Singh v. Gonzales, 417 F.3d 736, 739-40 (7th Cir. 2005) (finding that "simply being a member of a local [] police department during the pertinent period of persecution is not enough to trigger the statutory prohibitions on asylum"); Xie v. INS, 434 F.3d 136, 143 (2d Cir. 2006) ("[T] he mere fact that [the alien] may be associated with an enterprise that engages in persecution is insufficient by itself to trigger the effects of the persecutor bar") (emphasis added); see Hernandez v. Reno, 258 F.3d 806, 812, 814 (8th Cir. 2001) (explaining that evidence of an identifiable act of persecution - not just "any involvement with a persecutory group"-must be coupled with "evidence that an applicant ... has assisted or participated in [that] persecution" for the bar to apply) (emphasis added); Budiono v. Lynch, 837 F.3d 1042, 1048 (9th Cir. 2016) ("Generalized evidence that the applicant was involved with a persecuting group is not enough."); Miranda Alvarado, 449 F.3d at 927, 929 (citing Vukmirovic v. Ashcroft, 632 F.3d 1247, 1252 (9th Cir. 2004), for the rule that that "mere ... membership in an organization" is insufficient to trigger the persecutor bar).

243. See Evans, supra note 7, at 470, 526-527 ("Membership alone is not enough to come within the scope of these declarations") (citing 15 U.N. WAR CRIMES COMM'N, LAW REPORTS OF TRIALS OF WAR CRIMINALS 151 (1949); see also UNHCR, ELIGIBILITY GUIDELINES FOR ASSESSING THE INTERNATIONAL Protection NeEds of AsYlum-SEEKeRs From ERITREA 36 (2011) [hereinafter UNHCR ELIGIBILITY GUIDELINES] (stating that "membership in the Government security forces or armed opposition groups is not a sufficient basis in itself to exclude an individual from refugee status" and emphasizing the necessity to consider whether the applicant was "personally involved in acts of violence . . . or knowingly contributed in a substantial manner to such acts").

244. 1 Atle Grahl-Madsen, The Status of RefugeEs in INTERNATIONAL LAw 273-77 (1966); 15 U.N. WAR Crimes COMM'N, LAw Reports of Trials of WAR Criminals 170-75 (1949). 
membership "does not in itself entail individual liability for excludable acts." ${ }^{245}$

While the Board in Matter of Negusie did not provide much analysis on the level of connection required to constitute assistance or participation, it did affirm that "the adjudicator should consider ... the "nexus between the alien's role, acts, or inaction' and the persecution" identified in the initial steps. ${ }^{246}$ With regards to the significance of membership in a group with a poor human rights record, the Board was conspicuously silent. ${ }^{247}$ Although the Board in Matter of Negusie made no pronouncements on the significance of membership in a persecutory group, to the extent that the reasoning of Matter of $M-B-C$ - alters that analysis, the Board in Matter of Negusie made no effort to distance itself from the lax-procedure approach $^{248}$ adopted in $M-B-C-.{ }^{249}$

\section{Prior or Contemporaneous Knowledge}

Finally, to constitute culpable assistance or participation, the adjudicator must also find that the applicant possessed the requisite level of scienter, that is, prior or contemporaneous knowledge of the persecution such that the applicant knew that the consequences of her actions would assist in persecution. ${ }^{250}$ The Board in Matter of Negusie likewise affirmed the importance of scienter in the analysis of whether one's assistance may be determined to be culpable. $^{251}$ This element is also consistent with international law. Indeed, the war crimes tribunals observed that the definition of war crime "should exclude persons who had no knowledge of the criminal purpose or acts of the organization."252 Given the close recognized relationship between the

245. UNHCR ELIGIBILITY GUIDELINES, supra note 245, at If 19; $\mathbf{R}$ (on the application of JS) (Sri Lanka) v. Sec'y of State for the Home Dep't, [2010] UKSC 15, [2] (appeal take from [2009] EWCA Civ 364) (Lord Brown, SCJ) (Eng.) ("It is common ground between the parties ... that [inter alia] because of the serious consequences of exclusion for the person concerned ... more than mere membership of an organization is necessary to bring an individual within the article's disqualifying provisions.").

246. Matter of Negusie, 27 I. \& N. Dec. 347, 367 (B.I.A. 2018).

247. See generallyid.

248. See supra Section I.B.

249. Rather, as stated above, the Board in Matter of Negusie cited approvingly of Matter of $M-B-C$ See Matter of Negusie, 27 I. \& N. Dec. at 366.

250. Matter of D-R-, 27 I. \& N. Dec. 105, 120 (B.I.A. 2017) (the applicant must have "sufficient knowledge that the consequences of his actions may assist in acts" of persecution "to make those actions culpable"); Meng v. Holder, 770 F.3d 1071, 1074 (2d Cir. 2014) (requiring "sufficient knowledge" that one's actions may assist in the persecution in order to be found culpable); Quitanilla v. Holder, 758 F.3d $570,577\left(4^{\text {th }}\right.$ Cir. 2014) (the applicant must "have acted with scienter," or with "some level of prior or contemporaneous knowledge that the persecution was being conducted."); Haddam v. Holder, 547 F. App'x 306, 312 ( $4^{\text {th }}$ Cir. 2013) (requiring examination of the "intent, knowledge, and the timing" of the applicant's alleged assistance); Castañeda-Castillo v. Gonzales, 488 F.3d 17, 20 ( (st $^{\text {st }}$ ir. 2007) (noting that "the term 'persecution' strongly implies both scienter and illicit motivation"); Matter of J.M. Alvarado, 27 I. \& N. Dec. 27, 28 (B.I.A. 2017) (adopting the First Circuit's requirement that the applicant have "prior or contemporaneous knowledge" of the "persecutor acts" to apply the persecutor bar).

251. See Matter of Negusie, 27 I. \& N. Dec. at 367.

252. GRAHL-MADSEN, supra note 246, at 273-77; U.N. WAR CRIMES COMM'N, supra note 245, at 151; United States v. Carl Krauch, "The Farben Case," VIII Trials of War Criminals Before the Nuremberg Military Tribunals Under Control Council Law No. 10 (1952) (absolving individual plant 
persecutor bar and the war crimes provision of the Refugee Convention, the requirement of culpable prior or contemporaneous knowledge is in keeping with Congressional intent. ${ }^{253}$

****

As shown above, each substantive element of the above four-part test for determining whether one has assisted or participated in persecution was largely present in the Board's persecutor bar analysis in Matter of Negusie. There, the Board held that the record established that Mr. Negusie-who had been forcibly conscripted into the Eritrean military — had "guarded prisoners to make sure they did not escape" and even kept watch over some "who were placed in the hot sun as a form of punishment" resulting in at least one death. ${ }^{254}$ The Board also noted that the "prisoners ... were tortured ... on account of a protected ground," and that Mr. Negusie's actions were both connected to that persecution and conducted even while he knew that the persecution was occurring. ${ }^{255}$ As such, the Board found that the record established: (1) an identifiable act of persecution occurred involving sufficiently severe harm; (2) that it was inflicted on account of a protected characteristic; (3) that the applicant's conduct was connected to that act by standing guard throughout the persecution, and; (4) that he had contemporaneous culpable knowledge that persecution was occurring. ${ }^{256}$ The forgoing elements of assistance or participation in persecution should be deemed settled principles.

\section{The Necessary Procedural Safeguards Required to Apply the Persecutor Bar}

Contrary to the rule adopted in Matter of Negusie, I argue here that it is only when DHS has introduced evidence sufficient to allow the adjudicator to make the above four-part, preliminary findings by a preponderance of the evidence that the bar can be applied. ${ }^{257}$ The Board by contrast set DHS's burden at a prima facie standard and held that once DHS meets its burden to show that the bar may apply, the generic-relief regulation functions to switch the burden of proof to the putative refugee to prove dispositively that the bar does not apply. ${ }^{258}$ Above, I have already discussed why use of the genericrelief regulation is misguided. In the section below, I argue that the

\footnotetext{
managers from liability for crimes against humanity where they have functioned simply as members in the plant); Ezokola, [2013] 2 S.C.R. 678 at 796 (Can.) (concluding that "[a]t a minimum," exclusion from refugee protection "requires an individual to knowingly (or at the very least, recklessly) contribute in a significant way to the crime of criminal purpose of the group").

253. See supra Section I.A.

254. Matter of Negusie, 27 I. \& N. Dec. at 348-49.

255. Id.

256. Id.

257. See e.g., Budiono v. Lynch, 837 F.3d 1042, 1048 ( $9^{\text {th }}$ Cir. 2016) (" $[$ R]equir[ing] a threshold showing of particularized evidence of the bar's applicability," which involves putting forth "evidence of each element before the burden of proof shifts ..."). See infra Section IV.2. for further discussion of burdens of proof.

258. Matter of Negusie, 27 I. \& N. Dec. at 348-49.
} 
preponderance of the evidence standard is the most harmonious with the statute and analogous frameworks employed by the Board to address similar asylum and withholding bars. Additionally, I maintain that before the bar is actually applied, the applicant must be put on notice that the adjudicator has made these specific findings, and she must be given an opportunity to produce countervailing evidence related to one of those four findings, or otherwise establish a duress defense. ${ }^{259}$

In the normal course of most proceedings where the persecutor bar emerges, the prophylactic measures discussed here would require DHS to inform the applicant well in advance of any merits hearing that DHS intends to raise the persecutor bar with respect to specified acts. This would afford the applicant the opportunity to present evidence at the merits hearing to rebut the persecution allegation (and/or establish a defense such as duress). ${ }^{260}$ If DHS were not to provide such advance notice-and the persecutor bar is raised for the first time at the applicant's merits hearing-the applicant should be allowed to seek a continuance to develop appropriate evidence in response. ${ }^{261}$

\section{A. A Framework No Less Protective Than The Procedures The Board Has Adopted For Similar Bars With Less Serious Consequences}

The process for applying the persecutor bar should proceed as follows: First, the adjudicator should determine whether the applicant is eligible for asylum or withholding of removal. ${ }^{262}$ Second, if the applicant is otherwise eligible for protection, the adjudicator should determine whether DHS has submitted sufficient evidence to sustain the above four-part findings by a preponderance of the evidence such that the persecutor bar applies. ${ }^{263}$ Third,

259. See e.g., Matter of Y-L-, 24 I. \& N. Dec. at 155-60 ("Given the serious consequences of a frivolous finding," minimum "procedural safeguards" require (1) "specific finding[s]" by the IJ-that "tak[e] into account" the applicant's response-in relation to the substantive elements of a frivolous finding, (2) established by "a preponderance of the evidence" in the record, (3) made only after notice has been given, and (4) the applicant has had a sufficient and ample opportunity to respond.); Matter of A-G-G-, 25 I. \& N. Dec. 486, 501-03 (B.I.A. 2011) (setting forth a four-part "framework for making firm resettlement" determinations where "DHS bears the initial burden of establishing that [the] evidence indicates that a mandatory bar to relief applies," after which, the applicant must be given an opportunity to "rebut the DHS's . . evidence," or otherwise establish an exception applies).

260. See e.g., Matter of Y-L-, 24 I. \& N. Dec. at 159-160.

261. Id. This proposal is also consonant with the principles of international law. See AS (c.55"exclusion" certificate -process) Sri Lanka v. Sec'y of State for the Home Dep't [2013] UKUT 00571 (IAC), [28] (Eng.) ("It is the nature of litigation, certainly in the Immigration and Asylum Chamber, for new evidence or issues to arise during a hearing. If a party considers that they have not been given sufficient opportunity to deal with the new point, an application for an adjournment can be made. If the respondent's case on exclusion changes during a hearing this can be addressed in the same way, by an adjournment, short or longer, depending on the particular circumstances.").

262. See Matter of Negusie, 27 I. \& N. Dec. at 366; 8 U.S.C. $\$ \$ 1158($ b)(1)-(2); 1231(b)(3)(A)-(B) (The statutory text and overall structure support a sequenced analysis that first defines eligibility before proceeding to the exceptions to eligibility).

263. See Matter of Y-L-, 24 I. \& N. Dec. at 155-60 (discussing burdens and quantum of proof); Matter of J.M. Alvarado, 27 I. \& N. Dec. 27, 28 (B.I.A. 2017) (discussing the four elements of assistance in persecution); infra Section IV.A.2. 
the applicant should be given fair notice and ample opportunity to demonstrate that the government has not in fact met its burden in relation to one or more the above four-part findings of assistance or participation in persecution. ${ }^{264}$ If the applicant cannot rebut at least one of the preliminary findings, then the burden shifts to the applicant to establish a duress defense by a preponderance of the evidence. ${ }^{265}$

These minimum procedural safeguards for applying the persecutor bar are extrapolated from the frameworks the BIA has required in the firm resettlement bar and frivolous asylum bar contexts, analogous bars that serve as benchmarks for the safeguards proposed here. ${ }^{266}$ Given the relative gravity of these three bars - the persecutor bar being by far the most serious-it would be unreasonable to adopt in the persecutor bar context a set of procedures less protective than those the BIA has adopted in the firm resettlement and frivolous asylum bar contexts. ${ }^{267}$

It does not make sense to think that Congress would intend to bar mandatory protection even to refugees who face a certainty of persecution on the basis of less evidence and with fewer procedural safeguards than it requires in order to bar discretionary asylum relief to refugees who face only a reasonable possibility of persecution. While the firm resettlement bar renders an applicant ineligible for asylum, it is not a bar to withholding. ${ }^{268}$ Similarly, the frivolous asylum bar - though carrying even more serious and far-reaching consequences than the firm resettlement bar by rendering an applicant permanently ineligible for asylum and other relief under the Act- does not bar eligibility for withholding. ${ }^{269}$ Of the three bars, it is only the persecutor bar that results in permanent ineligibility for both asylum and withholding. ${ }^{270}$

In $A-G-G_{-}$, the Board identified a four-part framework for applying the firm resettlement bar that is informative to the task here of delineating the appropriate procedural safeguards with respect to the application of the persecutor bar. ${ }^{271}$ First, the Board held that "DHS bears the initial burden" to

264. See infra Section IV.A.2.

265. See Matter of Y-L-, 24 I. \& N. Dec. at 155-60; Matter of Alvarado, 27 I. \& N. Dec. at $28, \mathrm{n} .2$ (citing Castañeda-Castillo v. Gonzales, 17, 21 n.3 ( $1^{\text {st }}$ Cir. 2007) and 8 C.F.R. 1240.8(d)). Finally, only after it is determined that the applicant failed to establish a duress defense would the IJ actually apply the persecutor bar. See Matter of A-G-G-, 25 I. \& N. Dec. 486, 503 (B.I.A. 2011); Matter of Y-L-, 24 I. \& N. Dec. at $155-60$.

266. See Matter of A-G-G-, 25 I. \& N. Dec. at 501-02; Matter of $Y-L-, 24$ I. \& N. Dec. at 155-60.

267. See Matter of Khan, 26 I. \& N. Dec. 797, 804 (B.I.A. 2016) (noting the importance of adopting a standard that would result in a "harmonious [and symmetrical] statutory scheme") (citing FDA. V. Brown \& Williamson Tobacco Corp., 529 U.S. 120, 133 (2000) (explaining that in determining the meaning of a statute, a court must "interpret the statute 'as a symmetrical and coherent regulatory scheme' ... and "fit, if possible, all parts into an harmonious whole"))

268. Compare 8 U.S.C. $\S 1158$ (b)(2)(A) (containing a firm resettlement bar to asylum), with 8 U.S.C. $\S 1231$ (b)(3)(B) (omitting any firm resettlement bar for withholding).

269. See Matter of $Y-L-, 24$ I. \& N. Dec. at 154-155 (finding that the frivolous asylum bar makes one "permanently ineligible for any benefits under [the INA]," but it "shall not preclude [an applicant] from seeking withholding of removal").

270. See 8 U.S.C. $\$ 1158($ b)(2)(A); 8 U.S.C. $\$ 1231(b)(3)(B)$.

271. See Matter of A-G-G-, 25 I. \& N. Dec. at 501-02. 
present prima facie evidence of an offer of firm resettlement. ${ }^{272}$ To meet its burden, the Board explained that DHS must "secure and produce" direct evidence — or, when unavailable, indirect evidence that "has a sufficient level of clarity and force"- to "establish that [the applicant] is able to permanently reside in the country." 273 The "inquiry ends if DHS fails" to meet its burden "or the record does not otherwise establish the existence of an offer of firm resettlement." 274 However, if DHS has presented sufficient evidence of firm resettlement, then at the second step, the applicant must be given the opportunity to rebut DHS's evidence by showing that "an offer has not, in fact, been made" or that the applicant's circumstances would render her ineligible for such an offer. ${ }^{275}$ Third, the IJ must weigh "the totality of the evidence" and determine whether the applicant has "rebutted ... DHS's evidence." 276 Finally, if the adjudicator determines that the applicant was firmly resettled, the burden shifts to the applicant to establish by a preponderance of the evidence an exception applies. ${ }^{277}$ It is only after each of these steps has been analyzed that the adjudicator may actually apply the bar. ${ }^{278}$

Similarly, in the frivolous asylum bar context, the Board in $Y-L-$ recognized four "procedural safeguards" necessary "[g]iven the serious consequences of a frivolous finding." ${ }^{279}$ Among those procedural safeguards are: (1) notice to the applicant that filing a frivolous application will result in "permanent ineligibility for any benefits under the [INA] except for withholding of removal;" (2) "specific findings" related to the substantive elements of frivolousness (i.e., deliberate fabrication of material elements of an asylum claim); (3) "sufficient [and ample] opportunity" to respond to the allegations of "any deliberate, material fabrications upon which the IJ may base a finding of frivolousness;" and (4) the requirement that "the ultimate burden of proof [be] on the Government" and that the IJ "provide cogent and convincing reasons for finding by a preponderance of the evidence" the above substantive elements of frivolousness only "[a]fter taking into account the respondent's explanations."280

\footnotetext{
272. See id. at 496, 501 (emphasis added).

273. See id. at 501-02. (emphasis added).

274. See id. at 503 (emphasis added).

275. Id. at 503.

276. See id.

277. See id. Two exceptions are provided in the regulations to the firm resettlement bar. If the applicant can establish that "his ... entry into that country was a necessary consequence of his ... flight from persecution, that he ... remained in that country only as long as was necessary to arrange onward travel, and that he ... did not establish significant ties to that country," then the bar will not apply. 8 C.F.R. \& 208.15(a). Alternatively, if "the conditions of his ... residence ... were so substantially and consciously restricted by the authority of the country of refuge that he ... was not in fact resettled," then the bar does not apply. 8 C.F.R. $\$ 208.15$ (b).

278. See Matter of A-G-G-, 25 I. \& N. Dec. at 503.

279. Matter of Y-L-, 24 I. \& N. Dec. 151, 155 (B.I.A. 2007).

280. See id. at 155-60.
} 
Because the frameworks of $A-G-G$ - and $Y-L$ - were crafted in contexts involving consequences less severe than that of the persecutor bar, ${ }^{281}$ those decisions simply establish a floor for the minimum procedural safeguards required in the persecutor bar context. Given that the persecutor bar-as a mandatory ground of denial for even withholding - carries more profoundly devastating consequences than those in $A-G-G$ - and $Y-L-$, the minimum procedural safeguards in the persecutor bar context must at least meet, if not exceed, those provided in $A-G-G$ - and $Y-L$ - in order to provide "a symmetrical and coherent regulatory scheme." 282

Both $A-G-G$ - and $Y-L$ - place the initial burden of proof squarely on the government. ${ }^{283}$ And, while $A-G-G$ - states that the government's burden is to produce prima facie evidence, ${ }^{284}$ the more serious frivolousness bar requires "cogent and convincing reasons for finding by a preponderance of the evidence." ${ }^{285}$ Similarly, both decisions require some form of notice and opportunity to respond. ${ }^{286}$ Lastly, the decisions require that the adjudicator consider the applicant's response, and the availability of any exception, before determining whether the bars actually apply. ${ }^{287}$ The next section will utilize and adapt the procedural safeguards in $A-G-G$ - and $Y-L$ - to formulate safeguards for persecutor bar analyses.

\section{B. Proposed Procedural Safeguards}

In the persecutor bar context, (1) DHS must bear the initial burden of proof related to the substantive components of assistance in persecution; (2) the evidence must be sufficient to sustain the adjudicator's specific findings by a preponderance of the evidence; and (3) the bar cannot be applied until after there has been notice to the applicant, a fair opportunity to respond, and due consideration of any duress defense to the bar. Each of these procedural safeguards are discussed separately below.

281. As stated above, unlike the firm resentment bar and the frivolous asylum bar, the persecutor bar renders one ineligible for withholding of removal. See supra note 265-67 and accompanying text.

282. See Matter of Marcos Victor Ordaz-Gonzalez, 26 I. \& N. Dec. 637, 643 (B.I.A. 2015) (citing FDA. V. Brown \& Williamson Tobacco Corp., 529 U.S. 120, 133 (2000) (explaining that a it is imperative to "interpret the statute 'as a symmetrical and coherent regulatory scheme,'... and 'fit, if possible, all parts into a harmonious whole." ")).

283. Matter of $A-G-G-, 25$ I. \& N. Dec. at 496 ("DHS bears the initial burden"); Matter of $Y-L-, 24$ I. $\&$ N. Dec. at 158 ("the ultimate burden of proof [is] on the Government").

284. Matter of $A-G-G-, 25$ I. \& N. Dec. at 501.

285. Matter of $Y-L-, 24 \mathrm{I}$. \& N. Dec. at 158.

286. Matter of A-G-G-, 25 I. \& N. Dec. at 503; Matter of $Y-L-, 24$ I. \& N. Dec. at 155-56, 159-60.

287. See Matter of $A-G-G-, 25$ I. \& N. Dec. at 503 ("the [IJ] will consider the totality of the evidence presented by the parties to determine whether an [applicant] has rebutted DHS's evidence" before "finding the [applicant] firmly resettled," but will only apply the bar if the applicant fails to meet her burden on any exception to the firm resettlement bar); Matter of $Y-L-, 24$ I. \& N. Dec. at 157 ("plausible explanations offered by the respondent must be considered in the ultimate determination of whether the preponderance of the evidence supports a frivolousness finding"). 


\section{DHS Must Bear The Initial Burden Of Proof}

The statute and case law confirm that DHS bears the initial burden of introducing sufficient evidence - in relation to the above four specific substantive findings_-such that the adjudicator can apply the persecutor bar. Indeed, more than three decades ago, the Board held that while the persecutor bar is referenced within 101(a)(42)(A)'s refugee definition, an applicant does not bear the initial burden of proving she did not engage in persecution to establish she is a refugee. ${ }^{288}$ The Board in Acosta reasoned that:

"While the language of section 101(a)(42)(A) excludes from the definition of a refugee any person who 'ordered, incited, assisted, or otherwise participated in the persecution of any person,' we do not construe this language as establishing a fifth statutory element an alien must initially prove before he qualifies as a refugee. This provision is one of exclusion, not one of inclusion ..."289

Although the plain language of the statute assigns an applicant for asylum or withholding the burden of establishing eligibility for relief, Congress has been equally clear that this burden does not extend to the persecutor bar. ${ }^{290}$ The REAL ID Act of $2005,{ }^{291}$ reinforced Acosta's assignment of the applicant's burden of proof, confirming that the applicant does not bear any statutory burden to prove that the persecutor bar does not apply. Section 1231(b) (3)(C), as amended by REAL ID, provides that, in determining whether an applicant has demonstrated eligibility for withholding of removal, "the trier of fact shall determine whether the [applicant] has sustained [her] burden of proof ... in the manner described in clause (ii) and (iii) of section [1158(b) (1)(B)]," which describes in detail burdens of proof relevant to asylum. ${ }^{292}$ In turn, section 1158(b)(1)(B)(i), also amended by REAL ID, states that "the burden of proof is on the applicant to establish that the applicant is a refugee within the meaning of 101(a)(42)(A)." ${ }^{293}$ To meet that burden, section 1158 (b)(1)(B)(i) provides only that "the applicant must establish that race, religion, nationality, membership in a particular social group, or political opinion was or will be at least one central reason for persecuting the applicant.,"294 Consistent with Acosta, this "burden of proof" section makes no reference at all to any affirmative duty on the applicant to prove that the persecutor bar does not apply. ${ }^{295}$

\footnotetext{
288. See Matter of Acosta, 19 I. \& N. Dec. 211, 219 n.4 (B.I.A. 1985), overruled on other grounds by Matter of Mogharrabi, 19 I. \& N. Dec. 439 (B.I.A. 1987).

289. See Matter of Acosta, 19 I. \& N. Dec. at 219 n.4 (emphasis added).

290. See 8 U.S.C. $\$ \$ 1229 \mathrm{a}(\mathrm{c})(4), 1231(\mathrm{~b})(3)(\mathrm{B}), 1158(\mathrm{~b})(1)(\mathrm{B})$.

291. Pub. L. No. 109-13, 119 Stat. 231 (2005).

292. 8 U.S.C. $\$ 1231($ b $)(3)(C)$.

293. 8 U.S.C. $\$ 1158(\mathrm{~b})(1)(\mathrm{B})(\mathrm{i})$.

294. Id.

295. Id.; Matter of Acosta, 19 I. \& N. Dec. 211, 219 n.4 (B.I.A. 1985).
} 
Several decisions by the U.S. Court of Appeals and the BIA confirm that Congress has placed the initial burden related to the persecutor bar for an asylum or withholding applicant squarely upon the government. ${ }^{296}$ The Ninth Circuit reasoned that "[i]t is unreasonable to expect applicants for withholding of removal and other forms of relief to anticipate what bars might apply to their cases, and then to affirmatively rebut all of those bars." 297 Moreover, this burden allocation is consistent with the policy reasons underlying who should bear a burden of proof. The Supreme Court has explained that the burden of persuasion determines "which party loses if the evidence is closely balanced." ${ }^{298}$ Applying that observation here supports placing the burden of persuasion on DHS because the persecutor bar authorizes the removal of a putative refugee to a country where they face a clear probability of persecution. That potential death penalty should not be imposed lightly; procedure should not be set to impose it when the "evidence is closely balanced.",299

Likewise, international law supports putting the burden of proof squarely on the government in the persecutor bar context. Indeed, UNHCR's guidelines state that " $[\mathrm{u}]$ nder the 1951 Convention, responsibility for establishing exclusion lies with States." ${ }^{300}$ The guidelines also note that while in the eligibility context, "the burden of proof is shared between the applicant and the State (reflecting the vulnerability of the individual in this context) ...., several jurisdictions have explicitly recognized ... [that] the burden shifts to the State to justify exclusion under Article 1F.,"301

Accordingly, because of the textual structure and purpose of the bar and because of the Board's existing procedural frameworks in analogous contexts, DHS must bear the initial burden of proof in relation to the persecutor bar. ${ }^{302}$ On this point of procedure, the Board in Negusie agreed, holding that "the initial burden is on the DHS to show evidence that indicates that the

296. See Budiono v. Lynch, 837 F.3d 1042, 1049 (9th Cir. 2016); Gao v. U.S. Att'y Gen., 500 F.3d 93, 103 (2d Cir. 2007) (noting that "the government must "satisf[y] its initial burden of demonstrating that the persecutor bar applies"); Castañeda-Castillo v. Gonzales, 488 F.3d 17, 21 (1st Cir. 2007) ("[O]nce the government introduced evidence of the applicant's association with persecution, it then became Castaneda's burden ...”); Matter of Y-L-, 24 I. \& N. Dec. 151, 160 (B.I.A. 2007) (holding in the context of the frivolous asylum bar that "the ultimate burden of proof [is] on the Government") (emphasis added); see also Matter of A-G-G-, 25 I. \& N. Dec. 486, 501 (B.I.A. 2011) (holding that "DHS bears the initial burden of establishing that [the] evidence indicates that a mandatory bar to relief applies" in the firm resettlement context).

297. See Budiono, 837 F.3d at 1049 .

298. See Schaffer v. Weast, 546 U.S. 49,56 (2005).

299. Seeid.

300. See Note on the Exclusion Clauses, II 4, UNHCR Standing Comm., U.N. Doc. EC/47/SC/ CRP.29 (May 30, 1997), http://www.unhcr.org/en-us/excom/standcom/3ae68cf68/note-exclusionclauses.html.

301. See Background Note on the Application of the Exclusion Clauses: Article 1F of the 1951 Convention Relating to the Status of Refugees, TI 105-106, UNHCR (Sept. 4, 2003), https://www. refworld.org/docid/3f5857d24.html.

302. See Negusie v. Holder, 555 U.S. 511, 519 (2009) (noting that when interpreting a statute, the court must "look not only to the particular language, but to the design of the statute as a whole and to its object and policy"); Emergency Supplemental Appropriations Act for Defense, The Global War on Terror, and Tsunami Relief, 2005 (REAL ID Act), Pub. L. No. 109-13, 119 Stat. 231 (2005). 
alien assisted or otherwise participated in persecution." 303 Whether the government will continue to be allowed to meet its burden by running afoul of the rule of Moore v. Chesapeake \& Ohio Ry. Co., ${ }^{304}$ (i.e., a proposition is not established by disbelieving a person's denial of it), remains to be seen. ${ }^{305}$ However, given the BIA's past practice of finding, through an approach not clearly repudiated by the Board in Negusie, that the bar may apply (triggering a burden-switch to the applicant and a subsequent adverse credibility finding), ${ }^{306}$ it is imperative that the government's burden be set at a preponderance of the evidence.

\section{Only A Preponderance Of The Evidence Can Justify Application Of The Bar}

To actually apply the persecutor bar to an applicant otherwise eligible for withholding or asylum, the INA requires the Attorney General to "decide [or determine] that ... [the applicant] assisted or otherwise participated in ... persecution." 307 A preponderance of the evidence is required to make this determination; a mere possibility that an applicant assisted in persecution is not sufficient to apply the bar consistent with the statute. ${ }^{308}$

In the withholding and asylum context, facts established for purposes of eligibility are found using a preponderance of the evidence standard. ${ }^{309}$ Facts material to the frivolousness bar to relief are likewise held to the preponderance standard. ${ }^{310}$ As such, the same preponderance standard should be required for application of the persecutor bar. That interpretation is confirmed when the persecutor bar is read within the larger context of the other bars to asylum and withholding. Indeed, the language of the persecutor bar-which requires the adjudicator to "decide" or "determine" that the applicant assisted or participated in persecution - stands in contrast with the "danger to U.S. security," which merely requires "reasonable grounds for regarding" one a

303. See Matter of Negusie, 27 I. \& N. Dec. 347, 366 (B.I.A. 2018).

304. 340 U.S. 573,576 (1951).

305. Seeid.

306. See UNHCR, Beyond Proof: Credibility Assessment IN EU Asylum Systems 46, 214 (2013) (noting that "the credibility of asserted material facts should be assessed with reference to the entirety of the applicant's statements, including any additional information given to explain any apparent inconsistencies, vagueness or doubts regarding plausibility").

307. 8 U.S.C. § 1231(b)(3)(B)(i) (emphasis added); see also 8 U.S.C. § 1158(b)(1)(B)(i) (explaining that an applicant is not eligible for asylum if the Attorney General "determines that ... the alien ... assisted, or otherwise participated in ... persecution") (emphasis added).

308. See 8 U.S.C. $\$ 1158(\mathrm{~b})(1)(\mathrm{B})(\mathrm{i})$.

309. Matter of Acosta, 19 I. \& N. Dec. 211, 214-216 (B.I.A. 1985) ("It is the general rule" that the truth of allegations is established "by a preponderance of the evidence"); see e.g., Matter of C-A-L-, $21 \mathrm{I}$. \& N. Dec. 754, 759 (B.I.A. 1997) (holding that "internal resettlement [ground for denial] should be applied only if" the IJ or BIA can make that finding by "a preponderance of the evidence") (emphasis added).

310. See e.g., Matter of Y-L-, 24 I. \& N. Dec. 151, 157-58 (B.I.A. 2007) (holding that the IJ "must provide cogent and convincing reasons for finding by a preponderance of the evidence" the substantive elements of a frivolous finding). 
danger to security to apply that bar. ${ }^{311}$ The "reasonable grounds" standard is one "substantially less stringent ... than "preponderance of the evidence,", and is roughly equivalent to the "probable cause" standard. ${ }^{312}$ In contrast, the persecutor bar requires the adjudicator to actually determine that the applicant assisted or otherwise participated in persecution. ${ }^{313}$

Had Congress intended for the persecutor bar to apply when there were merely "reasonable grounds" to believe the applicant assisted or participated in persecution, or may have assisted or participated in persecution, it could have used that language. ${ }^{314}$ That it did not use the "reasonable grounds" language must be given effect. ${ }^{315}$ As such, it would be legal error and irreconcilable with the statute as a whole to hold that the persecutor bar could be applied on a lower standard, such as the "reasonable grounds for regarding" standard. $^{316}$

Rather, a preponderance of the evidence standard in the persecutor bar setting is required both by the plain language of the statute as well as the grave consequences the bar carries. ${ }^{317}$ As stated above, because a finding that an applicant has assisted in persecution constitutes a bar to even withholding of removal, the Board cannot adopt a standard of proof here less than that

311. Compare 8 U.S.C. $\$ \$ 1231(\mathrm{~b})(3)(\mathrm{B})(\mathrm{i})$, and 1158(b)(2)(A)(i), with 1231(b)(3)(B)(iii)-(iv), and 1158 (b)(2)(A)(iii)-(iv) (emphasis added).

312. See Deborah E. AnKer, LAw OF Asylum IN The U.S. \$ 6:23 (2015 ed.) (citing Matter of A-H-, 23 I. \& N. Dec. 774, 786 (A.G. 2005); Matter of U-H-, 23 I. \& N. Dec. 355, 356 (B.I.A. 2002) (finding that probable cause existed where an applicant was merely a member and supporter of a group designated as a terrorist organization)); see also Matter of R-S-H-, 23 I. \& N. Dec. 629, 640 (B.I.A. 2003); cf. Matter of Rodriguez-Majano, 19 I. \& N. Dec at 814-15 (stating that "mere membership in an organization, even one which engages in persecution, is not sufficient to" apply the persecutor bar). To the extent that the Board looked to Matter of $R-S-H$ - in Alvarado, as guidance in construing 1240.8(d) in the persecutor bar context, such reliance was misplaced given the disparate statutory language of the "danger to security" bar at issue in $R-S-H$-, and the persecutor bar at issue in Alvarado. See Matter of J.M. Alvarado, 27 I. \& N. Dec. 27,28 n.2 (B.I.A. 2017).

313. See McMullen v. INS, 788 F.2d 591, 598 n 2 (9th Cir. 1986) (noting that "[a] finding that there are 'serious reasons' to believe the alien committed a serious nonpolitical crime is far less stringent than a determination that the alien actually "ordered, incited, assisted, or otherwise participate in ... persecution," and suggesting, but not deciding, that the persecutor bar could require a "clear and convincing" standard) (emphasis added), overruled in part on other grounds by Barapind v. Enomoto, 400 F.3d 744, 751 (9th Cir. 2005).

314. Compare 8 U.S.C. $\$ 1158$ (b)(2)(A)(iv) (using the "reasonable grounds for regarding" language in the danger to security bar), with 8 U.S.C. $\$ 1158(\mathrm{~b})(2)$ (A)(i) (making no use of such language in the persecutor bar).

315. See INS v. Cardoza-Fonseca, 480 U.S. 421, 432 (1987) ("Where Congress includes particular language in one section of a statute but omits it in another section of the same Act, it is generally presumed that Congress acts intentionally and purposely in the disparate inclusion or exclusion.") (quoting Russello v. United States, 464 U.S. 16, 23 (1983)); Matter of C-W-L-, 24 I. \& N. Dec. 346, 352 (B.I.A. 2007) ("A provision that may seem ambiguous in isolation is often clarified by the remainder of the statutory scheme ... because only one of the permissible meanings produces a substantive effect that is compatible with the rest of the law.") (citing United'Sav. Ass'n of Texas v. Timbers of Inwood Forest Assoc., Ltd., 484 U.S. 365,371 (1988)).

316. See Cardoza-Fonseca, 480 U.S. at 432.

317. See Matter of Y-L-, 24 I. \& N. Dec. 151, $157-58$ ("Because of the severe consequences that flow from a frivolousness finding, the preponderance of the evidence must support an Immigration Judge's finding."); Gao v. U.S. Att'y. Gen., 500 F.3d 93, 98 (2d Cir. 2007) ("In evaluating a persecutor bar claim, it must be remembered that this provision authorizes the deportation of individuals who have established that they would likely be persecuted."). 
standard adopted in $Y$ - L-, where the consequences there did not include a bar to withholding.

International law standards also support a preponderance of the evidence standard for the persecutor bar. The Refugee Convention requires "serious reasons for considering that" the applicant has, inter alia, "committed ... a war crime" to apply the bar. ${ }^{318}$ Other signatories to the Refugee Convention understand the "serious reasons for considering" language in the Exclusionary provisions to require a high standard of proof. ${ }^{319}$ The UK Supreme Court, for example, stated that exclusionary clause "should be interpreted restrictively and applied with caution" and that "[t]here should be a high threshold "defined in terms of the gravity of the act in question, the manner in which the act is organized, its international impact and long-term objectives, and the implications for international peace and security." 320 In selecting this language, international law scholars have understood the Convention to incorporate the requirement of individual culpability for two purposes: (1) to exclude those undeserving of refugee protection, and (2) to prevent serious criminals from evading punishment for their crimes. ${ }^{321}$ Neither of these purposes is well-served by applying the bar on the mere possibility that one might have been involved in persecution.

\section{The Applicant Must Have Notice And Opportunity To Respond}

After DHS meets its initial burden of proof in relation to the persecutor bar, the applicant should be informed of that result and provided a sufficient opportunity to rebut DHS's evidence, consistent with necessary due process protections. ${ }^{322}$ This requirement is consistent with the procedural safeguards

318. Convention, supra note 49 , art. $1 \mathrm{~F}$.

319. See AS (c.55 "exclusion" certificate -process) Sri Lanka v. Sec'y of State for the Home Dep't [2013] UKUT 00571 (IAC) (Eng.), [43] (quoting Al-Sirri and noting that "although a domestic standard of proof could not be imported into the Refugee Convention ... ' [ $t$ ]he reality is that there are unlikely to be sufficiently serious reasons for considering the applicant to be guilty unless the decision-maker can be satisfied on the balance of probabilities that he is." ") (emphasis added); see also supra note 25.

320. Al-Sirri v. Sec'y of State for the Home Dep't; DD (Afghanistan) v. Sec'y of State for the Home Dep't [2012] UKSC 54, [16], [2013] 1 AC 745 (Eng.) (citing 1 ATLE GRAHL-MAdSEN, THE Status OF REFUGEES IN INTERNATIONAL LAW 283 (1966)).

321. See James C. Hathaway \& Michelle Foster, The Law of Refugee Status 525 (2d ed. 2014); James C. Hathaway, The Michigan Guidelines on the Exclusion of International Criminals, 35 Mich. J. INT'L L. 3, 7 (2013); Joined Cases C-57/09 \& C-101/09, Bundesrepublik Deutschland v. B \& D, 2010 E.C.R. I-10979.

322. See e.g., Matter of Y-L-, 24 I. \& N. Dec. 151, 159-60 (In applying similar safeguards, the BIA has held that "[i]n some cases, the Government may raise the issue ..... [i]n other situations, the Immigration Judge may raise the issue and afford the respondent an opportunity to respond," but the bar may not be applied unless the applicant "has had sufficient opportunity to" respond). The Court has long held that the "touchstone" of due process is the requirement that proceedings be fundamentally fair, which includes the right to notice and to be heard. See Gangon v. Scarpelli, 411 U.S. 778, 790 (1973); Mathews v. Eldridge, 424 U.S. 319, 333 (1976); Yamataya v. Fisher, 189 U.S. 86, 101 (1903) (explaining in the context of deportation proceedings that "no person shall be deprived of his liberty without opportunity, at some time, to be heard"); Zadvydas v. Davis, 533 U.S. 678, 693 (2001) ("[T]he Due Process Clause applies to all 'persons' within the United States, including" noncitizens); Plyler v. Doe, 457 U.S. 202, 210 (1982) ("E]ven ... [those] whose presence in this country is unlawful, have long been recognized as "persons' guaranteed due process of law by the Fifth ... Amendment[]."). 
established in $Y$ - $L$-. As stated above, the Board in $Y$ - $L$ - held that a frivolousness finding may only be made if the IJ or BIA is "satisfied that the applicant, during the course of the proceedings, has had sufficient opportunity to account for any discrepancies or implausible aspects of the claim." 323 The Board explained that "[i]n order to afford a sufficient opportunity," an IJ should "bring this concern to the attention of the applicant prior to the conclusion of the proceedings." 324 Additionally, the Board required that "plausible explanations offered by the respondent ... be considered in the ultimate determination whether the preponderance of the evidence supports a frivolousness finding.",325

Given the disparate gravity of a frivolousness finding (that does not bar eligibility to withholding), and the persecutor bar (which does), the Board in Matter of Negusie erred in adopting procedural safeguards in the persecutor bar context less protective than those provided by $Y-L-$. Rather, the procedural safeguards in relation to the persecutor bar must be adequate to ensure that bona fide refugees are not unjustly subject to the bar, a goal entirely consistent with the Refugee Convention. ${ }^{326}$

$$
* * *
$$

Only after (1) DHS has introduced sufficient evidence to allow the adjudicator to make the above four preliminary findings, (2) the applicant has been given fair notice and opportunity to respond, and (3) the adjudicator has determined that the applicant failed to rebut DHS's evidence, should it be permissible to apply the persecutor bar. Before the bar is actually applied, however, the applicant should be given the opportunity to show by a preponderance of the evidence that she qualifies for the duress defense. ${ }^{327}$ This final step is in keeping with the analogous firm resettlement analysis, which also shifts the burden of proof to the applicant to establish an exception applies. ${ }^{328}$ If the applicant fails to meet her burden to demonstrate that her assistance or participation in persecution was the result of duress, then and only then should the IJ actually apply the bar.

\footnotetext{
323. Matter of $Y-L-, 24$ I. \& N. Dec. at 159 (emphasis added).

324. Id.

325. Id. at 157 .
}

326. Al-Sirri v. Sec'y of State for the Home Dep't; DD (Afghanistan) v. Sec'y of State for the Home Dep't [2012] UKSC 54, [16], [2013] 1 AC 745 (Eng.) (finding that Article 1F(c) should be "interpreted restrictively and applied with caution").

327. See Matter of Negusie, 27 I. \& N. Dec. 347, 366 (B.I.A. 2018); Gao v. Att'y Gen., 500 F.3d 93, 103 (2d Cir. 2007) ("[O]nce the government has satisfied its initial burden of demonstrating that the persecutor bar applies, the burden would then shift to the applicant."); Pastora v. Holder, 737 F.3d 902, 906-07 (4th Cir. 2013) (Because the "totality of the specific evidence ... was sufficient to indicate that the persecutor bar applied," the burden shifted to the applicant.); Castañeda-Castillo v. Gonzales, 488 F.3d 17, 21 (1st Cir. 2007) ("[O]nce the government introduced evidence of the applicant's association with persecution, it then became Castañeda's burden."); Hernandez v. Reno, 258 F.3d 806, 812, 814 (explaining that once there is "evidence that an applicant ... has assisted or participated in persecution," the applicant must bear the burden.) (emphasis added).

328. See Matter of A-G-G-, 25 I. \& N. Dec. 486, 503 (B.I.A. 2011) (if the adjudicator determines that the applicant was firmly resettled, the burden shifts to the applicant to establish by a preponderance of the evidence an exception applies); supra note 279 and accompanying text. 


\section{ConClusion}

The structured and sequenced framework proposed in this article would ensure a fair evaluation of the evidence with appropriate burdens of proof and sufficient procedural safeguards consistent with the statute and due process, which would focus the bar's application on bona fide human rights abusers. At the core of this approach is an outright rejection of the use of the generic-relief, burden shifting regulation in the persecutor bar context.

The framework previously adopted by the Board prior to Matter of Negusie allowed for application of the bar when an applicant merely might have assisted in persecution. This lax-procedure approach-anchored in the generic-relief regulation as most saliently displayed in Matter of $M-B-C$-'s reasoning - belies a poor policy determination: that it is preferable to erroneously apply the bar than to run any risk of granting protection to possible participants in persecution. Such an approach strongly favors false positives even where mistaken application of the bar is tantamount to a death sentence and does not align with the reasoning expressed in the establishment of standards for similar bars.

In contrast, the procedural safeguards for which I advocate here are rooted in the normative judgment, consistent with the principles that undergird the Refugee Convention, that the greater evil to be eschewed in such adjudications is erroneously sending innocent refugees back to their deaths. While bona fide human rights abusers should not be given safe haven, this objective must not be so vehemently pursued that it is accomplished at the expense of innocent refugees' lives. Because Matter of Negusie neither admitted $M-B-C$ ' $s$ error, nor dispositively ended the lax-procedures it adopted, more work is needed to shore up protective procedural safeguards for refugees accused of assisting or participating in persecution. The procedural safeguards and rationale enumerated in this article can serve as a launch point for scholars and litigators alike to advance this crucial work. 